\title{
MONETARY POLICY AND EXCHANGE RATE PASS-THROUGH
}

First Draft: July 2001

This Draft: June 2004

Joseph E. Gagnon and Jane Ihrig*

Abstract: The pass-through of exchange rate changes into domestic inflation appears to have declined in many countries since the 1980s. We develop a theoretical model that attributes the change in the rate of pass-through to increased emphasis on inflation stabilization by many central banks. This hypothesis is tested on twenty industrial countries between 1971 and 2003. We find widespread evidence of a robust and statistically significant link between estimated rates of pass-through and inflation variability. We also find evidence that observed monetary policy behavior may be a factor in the declining rate of pass-through.

Keywords: inflation targeting, Taylor rule, exchange rate pass-through JEL: E58, F40

* Joseph.E.Gagnon@frb.gov (corresponding author, O:202-452-2528, F:202-872-4926) and Ihrig@frb.gov (O:202-452-3372, F:202-736-5638); Division of International Finance, Board of Governors of the Federal Reserve System, 2000 C Street NW, Washington, DC 20551. We would like to thank Sebastien Bradley and Alisa Wilson for invaluable research assistance. We are also grateful to Neil Ericsson, Ray Fair, Linda Goldberg, Giovanni Olivei, John Rogers, Ted Truman, Jonathan Wright, Kei-Mu Yi and participants in workshops at the Federal Reserve Banks of Atlanta and New York and the Division of International Finance for helpful guidance and comments. The views in this paper are solely the responsibility of the authors and should not be interpreted as reflecting the views of the Board of Governors of the Federal Reserve System or of any other person associated with the Federal Reserve System. 


\section{Executive Summary}

The pass-through of exchange rate changes into domestic inflation appears to have declined in many countries since the 1980s. Prominent examples include the United Kingdom and Sweden after 1992 and Brazil in 1999. We develop a theoretical model that attributes the change in the rate of pass-through to increased emphasis on inflation stabilization by central banks in these countries. Simply put, when a central bank acts aggressively to stabilize the domestic inflation rate it tightens policy to offset any inflationary impetus from a rise in import prices. This policy reaction holds down price increases in other sectors so that overall inflation remains stable. When agents correctly understand the central bank's intentions, they are less likely to try to pass-through cost increases, including those arising from exchange rate depreciations.

We test this hypothesis on twenty industrial countries between 1971 and 2003. First, we show that countries with low and stable inflation rates--presumably reflecting central bank policies--tend to have low estimated rates of pass-through from exchange rates to consumer prices. Second, we note a decline in both the level and variability of inflation in many countries over this period. We create two sub-samples, with sample break dates chosen independently for each country, based on the observed behavior of inflation, previous research on monetary policy behavior, and official adoption of inflation targets by central banks in some countries. We show that countries in which either the level or the standard deviation of inflation declined substantially from the first to the second sub-sample tended to have large declines in estimated rates of pass-through.

Finally, we test a more direct connection between monetary policy and pass-through. We estimate Taylor-type monetary policy rules using the forward-looking specification of Clarida, 
Gali, and Gertler (1998). In a cross-country regression using the full sample, we find no statistically significant relationship between estimated exchange rate pass-through and the estimated monetary policy parameters. However, there is a statistically significant relationship between changes in estimated pass-through across the two sub-samples and changes in monetary policy parameters. In particular, pass-through tended to decline the most in countries where monetary policy shifted strongly toward stabilizing inflation, as evidenced by an increase in the responsiveness of policy interest rates to expected inflation. 


\section{Introduction}

In the 1990s several countries experienced episodes of large real exchange rate depreciations that did not lead to significant increases in domestic inflation. The experiences of Sweden and the United Kingdom in 1992 are two widely cited examples. A potential explanation of this phenomenon is that central banks in these countries have articulated more or less formally an enhanced commitment to keeping inflation low since at least the beginning of the 1990s. In such an environment, firms are less keen to pass through fluctuations in their input prices to output prices both because the central bank applies countervailing pressure to aggregate demand contemporaneously, and because firms believe that the central bank will be successful in stabilizing inflation in the future.

This paper proposes that the anti-inflationary actions and credibility of the monetary authority are important factors behind the reduced pass-through of exchange rate changes into consumer price inflation. We develop a simple theoretical model that explains how monetary policy influences inflation expectations and exchange rate pass-through at the macroeconomic level. In this model, when the monetary authority focuses strongly on stabilizing inflation, there is less pass-through of exchange rate movements into consumer prices. We then examine the monetary and inflation experiences of a sample of industrial countries since the early 1970s. Empirical results indicate a robust and significant link between the rate of pass-through and the mean and variability of consumer price inflation. Direct tests using estimated monetary policy rules suggest that as a monetary authority increases its emphasis on fighting inflation it reduces the rate of pass-through. 
Several studies have identified a reduction in exchange rate pass-through in various countries. ${ }^{1}$ For example, Cunningham and Haldane (1999) document the low pass-through of sterling depreciation in 1992-93 as well as the low pass-through of sterling appreciation in 199697. Taylor (2000) discusses the cases of Sweden and the United Kingdom in 1992-93 and Brazil in 1999. Goldfajn and Werlang (2000) examine episodes of large depreciations in seven emerging markets and five industrial countries in the 1990s. In all cases, Goldfajn and Werlang find that pass-through was less than would have been predicted by their empirical model using data for the 1980s and 1990s. Norambuena (2003) confirms this result for Chile after 1991. Laflèche (1996-97) discusses the surprisingly low pass-through of the Canadian depreciation of 1992-94 compared with previous pass-through episodes. ${ }^{2}$ One of the main contributions of our study is to explicitly compare the evolution of rates of pass-through in a number of countries.

Both Taylor (2000) and the Bank of Canada have conjectured that changes in passthrough behavior may be due to changes in the orientation of monetary policy. According to the Bank of Canada's November 2000 Monetary Policy Report (p. 9) "the low-inflation environment itself is changing price-setting behavior. When inflation is low, and the central bank's commitment to keeping it low is highly credible, firms are less inclined to quickly pass higher costs on to consumers in the form of higher prices." Not many studies, however, have tried to link pass-through to monetary policy empirically. Parsley and Popper (1998) estimate passCPI.

${ }^{1}$ We focus here on studies of pass-through to broad measures of inflation, such as the

${ }^{2}$ In a study of pass-through at different stages of the distribution process, McCarthy (2000) finds that eliminating the years prior to 1983 tends to reduce estimated pass-through in a sample of industrial countries. 
through for U.S. non-durable goods by industry, recognizing the role that policy plays in determining the observable relationships between exchange rates and prices, and they find evidence at the industry level that U.S. monetary policy does influence pass-through. Here we consider twenty industrial countries and focus on the aggregate price index associated with monetary policy, which is typically the headline consumer price index.

A key contribution of our study is the formal derivation of the linkage between monetary policy and exchange rate pass-through to consumer prices. ${ }^{3}$ Using a simple macro model, we demonstrate that when a monetary authority increases its emphasis on fighting inflation, specifically through changes in its policy reaction function, the rate of pass-through declines. ${ }^{4}$

We test our model's hypothesis on quarterly data from twenty industrial countries between 1971 and 2000. Five of these countries -- with a history of moderately high inflation -adopted explicit and relatively low inflation targets as objectives for monetary policy in the early 1990s. In order of formal adoption of the new regimes, these countries are New Zealand, Canada, the United Kingdom, Sweden, and Australia. ${ }^{5}$ Because of their striking changes in policy regimes, these five countries form a natural experiment with which to test for the impact

${ }^{3}$ Devereux, Engel, and Storgaard (2003) derive a relationship between the currency of invoicing and monetary policy which provides a short-run link between monetary policy and pass-through that is complementary to the long-run relationship developed in this paper.

${ }^{4}$ Choudhri, Faruqee, and Hakura (2002) derive a negative relationship between mean expected inflation and macro pass-through based on a microeconomic analysis of firm pricing behavior that does not model the macroeconomic role of monetary policy.

${ }^{5}$ Freeman and Willis (1995) provide background on the early experiences of the first four of these five. While there is some evidence from long-term interest rates that the new policy regimes may not have been immediately and fully credible, inflation rates did come down faster than almost anyone expected and policy credibility grew with the observed success in fighting inflation. 
of monetary policy on exchange rate pass-through. Ten other countries in our sample ${ }^{6}$ - many of which also have histories of moderately high inflation - increased their exchange rate links to Germany at various points over the past 30 years, culminating in monetary union with Germany at the end of the sample. Finally, we analyze five other industrial countries (Germany, Japan, Norway, Switzerland, and the United States) with more or less independent monetary policies throughout the sample. Although only five of our countries adopted explicit inflation targets, monetary regimes in the remaining countries may have moved toward adopting implicit inflation targets.

We estimate the pass-through of exchange rate changes to consumer price inflation in each of these countries over the entire sample period, to make cross-country comparisons, as well as for two sub-samples for each country, to examine changes over time. We find that estimated rates of pass-through vary across countries and that these rates declined in the second sample period for 18 of our 20 countries. Next, we show that estimated pass-through coefficients are very significantly correlated with the standard deviation of the inflation rate, whether examining cross-country levels of pass-through and inflation variability over the entire sample or looking at changes in each country's pass-through and changes in inflation variability over time. Finally, as a more direct test of our theory, we estimate forward-looking Taylor-type monetary policy rules for these countries and attempt to correlate components of these policy rules with estimated rates of pass-through. The results suggest that as a monetary authority increases its emphasis in fighting inflation it reduces the rate of pass-through.

\footnotetext{
${ }^{6}$ Austria, Belgium, Finland, France, Greece, Ireland, Italy, the Netherlands, Portugal, and Spain.
} 
We now turn to section II which presents the theoretical model highlighting the link between monetary policy and pass-through. We test the model's implications in Section III. Concluding comments are in Section IV.

\section{A Simple Model}

This section explores the relationship between exchange rate pass-through and monetary policy in the context of a simple macro model with rational expectations. Our objective is to show how the implied correlation between exchange rate changes and inflation depends on the monetary policy regime. The six equations of our model are as follows, where all variables are in logarithms except the interest rate:

$y_{t}=\rho 1 y_{t-1}+\rho 2 y_{t+1}+(1-\rho 1)(1-\rho 2)\left[\alpha\left(e_{t}+c_{t}^{*}-c_{t}\right)-\beta\left(i_{t}-\Delta p_{t+1}\right)\right]+u_{t}$

$$
p_{t}=\phi\left(e_{t}+c_{t}^{*}\right)+(1-\phi) c_{t}+z_{t}
$$

$$
\Delta c_{t}=\rho 3 \Delta c_{t-1}+(1-\rho 3) \Delta c_{t+1}+\gamma y_{t}+x_{t}
$$

$$
e_{t}=E_{t} e_{t+1}-i_{t}+i_{t}^{*}+r p_{t}
$$

$$
r p_{t}=\rho 4 r p_{t-1}+v_{t}
$$

where $\alpha, \beta, \gamma, \phi, \mu, \lambda, \rho 1-\rho 5>0$ 
Equation (1) states that aggregate demand responds positively to the real exchange rate (defined as exchange-rate adjusted foreign costs relative to domestic costs) and negatively to the real interest rate, with a demand shock, $u$. Lagged adjustment is captured by the parameter $\rho 1$. A role for geometrically weighted expectations of future real exchange rates and real interest rates is captured by the parameter $\rho 2$, giving the equation the form of an Euler equation under costly adjustment. Equation (2) is an expectations-augmented Phillips curve for domestic cost, $c$, similar to those developed by Fuhrer and Moore (1995) and Christiano, Eichenbaum, and Evans (2001), where $x$ is a domestic supply shock. The consumer price, $p$, is a weighted average of import costs and domestic costs plus a markup shock, $z$, as presented in equation (3). ${ }^{7}$ Equation (4) is a standard uncovered interest rate parity relation. Expected exchange rate appreciation equates any difference between domestic and foreign interest rates, except for a risk premium, $r p$. The risk premium is driven by shocks, $v$, with autocorrelation $\rho 4$ (equation (5)). Equation (6) is a monetary policy rule in the style of Taylor (1993) and Clarida, Gali, and Gertler (1998), where $\pi$ is the target inflation rate, $\mu$ represents the strength of the monetary authority's response to deviations of inflation from its target, $\lambda$ is the response to fluctuations of output, and $w$ is a policy shock. Note that $w$ may also be interpreted as a temporary shock to the inflation target. We will interpret a regime shift toward "inflation targeting" as some combination of an

${ }^{7}$ In this paper, we assume that direct pass-through of exchange rate changes into the imported component of consumer prices is constant. Campa and Goldberg (2002) find some evidence that a more stable macroeconomic environment tends to reduce pass-through to import prices, which would strengthen our theoretical results. They also find that compositional shifts within imported goods have tended to reduce pass-through over time. Olivei (2002) also finds evidence that pass-through into U.S. import prices has declined over time. None of these changes in pass-through at the import price level are large enough to explain more than a small fraction of the estimated changes in pass-through at the consumer price level. 
increase in $\mu$ and changes in the other parameters that lead to less variance of inflation around its target. ${ }^{8,9}$ Woodford (2003) shows that a rule of this form represents an optimal monetary policy under plausible assumptions. Note that our model is normalized so that equilibrium values of aggregate demand, the real exchange rate, the risk premium, and the real interest rate are all zero. The equilibrium value of the inflation rate is $\pi$, and the levels of domestic costs, consumer prices, and the exchange rate will drift over time reflecting the cumulative impact of all past shocks.

In order to determine the impact of changing monetary policy regimes on exchange rate pass-through, we employ Monte Carlo techniques for specific parameterizations of the model. We first assume that $p^{*}$ and $i^{*}$ are exogenous and set to zero for simplicity. ${ }^{10}$ We also assume that the shocks, $u, x, z, v$, and $w$ are independently and normally distributed with no serial correlation. We then generate realizations of the shocks and solve the model repeatedly to build up artificial samples of 100 periods each. For each sample, we estimate the rate of pass-through as the long-run regression coefficient of inflation on the change in the exchange rate with lags (as in Section III below); then we calculate the average pass-through estimate across 1000 trials

${ }^{8}$ Fair (2001) finds that the estimated value of $\mu$ nearly doubled in the United States after 1982, when policy succeeded in achieving relatively low and stable inflation.

${ }^{9}$ Inflation targeting has also been associated with a reduction in the mean inflation rate, $\pi$, but a permanent shift in the average level of inflation does not by itself affect the correlation of inflation and exchange rate changes in this model.

${ }^{10}$ If both foreign and domestic monetary policy properties change in a similar direction, the implications for pass-through derived here will be dampened, but not eliminated. Limited experiments with an expanded model that includes a foreign inflation equation and foreign monetary policy suggest the impact of changes in foreign monetary policy regimes affects domestic pass-through, but the size of the effect is substantially smaller than the effect of an equivalent change in domestic policy regime. 
and report this as the model's implied rate of pass-through. ${ }^{11}$ We repeat this process for different numerical values of the parameters in order to understand the relationship between monetary policy and pass-through over a wide range of the parameter space.

The first step is to determine base values of the model parameters to be consistent with the data. The parameter $\alpha$ captures the extent to which real exchange rate movements affect aggregate demand. This effect can be broken down into three components: 1) the pass-through of exchange rates into import prices; 2) the elasticity of domestic and foreign import demand with respect to import prices; and 3) the share of imports and exports in GDP. Goldberg and Knetter (1997) provide a discussion of the literature on pass-through to import prices. Typically 50 to 100 percent of an exchange rate change is passed through to import prices, with estimates for U.S. imports at the bottom of this range. Higher rates of pass-through imply a greater effect of exchange rates on real activity. Trade price elasticities in aggregate data are generally estimated around or somewhat below unity; a range of 0.5 to 1 appears reasonable. ${ }^{12}$ Again, higher elasticities imply more impact of exchange rates on activity. The share of imports in GDP ranges from around 10 percent in Japan and the United States to over 80 percent in Belgium and Ireland, with export shares similar to import shares in each country. Combining these three ranges and adding up the effects through imports and exports yields a range of values for $\alpha$ from 0.05 to 1.6. However, the upper end of this range should be discounted substantially, as countries with very large trade shares are likely to have relatively low trade price elasticities and

\footnotetext{
${ }^{11}$ Pass-through coefficients for the base model using 1000 trials were within 2 percent of estimates based on 100 trials and 0.2 percent of estimates based on 10,000 trials.

${ }^{12}$ See, for example, Table 1 in Hooper, Johnson, and Marquez (2000).
} 
rates of pass-through into export prices, reflecting the fact that imported inputs are a large share of the value of exports, thereby damping the effect of the exchange rate on competitiveness. We choose a base value of $\alpha=0.1$ and we consider $\alpha=0.3$ as an alternative.

According to simulations of the Federal Reserve's FRB/US model, as documented in Table 3 of Reifschneider, Tetlow, and Williams (RTW 1999), a sustained reduction of one percentage point in the real short-term interest rate in FRB/US leads to a one percentage point increase in GDP after two years. This would imply a value of $\beta=1$, but the FRB/US simulation includes an endogenous exchange rate depreciation which accounts for about 15 percent of the impact on output. Thus, we set $\beta=1$ in our base case and consider 0.5 in an alternative case. Research on monetary conditions indicators suggests that the ratio of $\beta$ to $\alpha$ is likely to be between 1 and 10 for most industrial countries, lending further support to these parameter values. $^{13}$ The lag and lead coefficients $(\rho 1$ and $\rho 2)$ were set equal to 0.5 , which yielded simulated paths that roughly matched the average output dynamics of the industrial countries in the 1990s.

As in Christiano, Eichenbaum, and Evans (2001), we set the lag parameter in the Phillips Curve, $\rho 3$, at 0.5. Table 4 of RTW (1999) shows that, in response to a demand shock, the U.S. price level increases by about one-third of the percentage increase in output after two years. Brayton, Roberts, and Williams (1999) estimate a smaller price effect of around 0.1 after one year, which presumably would be larger for a two or three year horizon. We choose a base value of $\gamma=0.005$ to match these price responses to demand shocks and consider an alternative value of 0.02 .

\footnotetext{
${ }^{13}$ See, for example, Freedman (1994) and IMF (1996).
} 
The parameter $\phi$ captures the direct effect of exchange rates through import prices into consumer prices. Based on a pass-through range of 50 to 100 percent and a share of imports between 10 and 80 percent of GDP (as discussed above) we have a range for $\phi$ of 0.05 to 0.8 . Once again, we should greatly discount the high end of this range, since it is based on high shares of imports that are processed for export and it is not indicative of the true import share of consumption. The low end of this range corresponds well with results for the United States from the FRB/US simulations discussed above. We take $\phi=0.05$ as our base case and consider 0.2 as an alternative.

A large body of literature, surveyed in Froot and Thaler (1990), finds evidence of highly autocorrelated and apparently exogenous risk premiums in the foreign exchange markets under the assumption of rational expectations and Gaussian shocks. We assume an autocorrelation parameter, $\rho 4$, of 0.95 , which yields real exchange rate dynamics close to those observed among industrial countries in the 1990s.

Taylor (1993) found that a monetary policy rule as specified by equation (4) with $\mu=1.5$ and $\lambda=0.5$ tracked the U.S. federal funds rate quite well in the 1980s. Others, including Clarida, Gali, and Gertler (1998) and Fair (2001), estimate variants of this equation for the United States and other countries. Their results yield estimates of $\mu$ between 1.1 and 2.0, and $\lambda$ between 0 and 0.7. ${ }^{14}$ In the empirical work of the next section, we obtain estimates of $\mu$ in the most recent subsample that average 2.5 and an average estimate of $\lambda$ of 1.3 , with much smaller values in the earlier subsample. Values of $\mu$ greater than 1 are necessary for a unique and stable solution to

\footnotetext{
${ }^{14}$ Fair (2001) uses the unemployment rate instead of the output gap. Applying an Okun's Law proportion of 2 between changes in the output gap and changes in unemployment, yields an implied long-run value of $\lambda=0.7$.
} 
the model. We take $\mu=2.0$ and $\lambda=0.5$ for our base case, and consider $\mu=1.5$ and $\lambda=1$ as separate alternatives. We assume a lag parameter, $\rho 5$, of 0.5 , which yields simulation dynamics roughly in line with historical experience for the industrial countries. We note that the inflation target, $\pi$, has no impact on pass-through and has been set to zero. ${ }^{15}$

Finally, the values of the shock standard deviations $\left(\sigma_{u}, \sigma_{v}, \sigma_{w}, \sigma_{x}, \sigma_{z}\right)$ were chosen to yield standard deviations of the first differences of the simulated variables that are reasonably close to the average standard deviations observed for industrial countries in the 1990s. Table 1 presents some properties of data generated by the model relative to the observed data for industrial countries. The first four columns display the first-order autoregressive coefficients of output, inflation, the real exchange rate, and the interest rate. The first row contains average autoregressive coefficients obtained by regressions on data created by stochastic simulation of the model with the base case parameters. The second row contains average autoregressive coefficients on data from 20 industrial countries over the second sub-sample, where the data and sample periods are defined in Section III below. The last four columns present the standard errors of the first differences of these variables (inflation is already expressed as a first difference). Once again, the model data and observed data match up fairly well.

The left side of Table 2 displays the average long-run Monte Carlo pass-through coefficients from a regression of inflation on exchange rate changes with lags. Each cell corresponds to a different combination of model parameters. The right side displays the average standard deviations of inflation in the Monte Carlo simulations. The cells that are highlighted

\footnotetext{
${ }^{15}$ The simulations allow for negative nominal interest rates which should be interpreted as deviations around the sum of the equilibrium real interest rate and the target inflation rate.
} 
represent the rate of pass-through and standard deviation of inflation implied by the base case parameters described above. The four columns on each side of the table correspond to different combinations of monetary policy parameters: the first column is the base case, the second column has a reduced inflation coefficient, the third column has a higher output gap coefficient, and the fourth column sets the policy lag to zero. ${ }^{16}$ The rows of the table correspond to different values of the remaining model parameters.

By comparing the pass-through coefficient in the first column ("Base") with pass-through in second column, we learn that a stronger emphasis on inflation stabilization (the first column) does indeed lead to lower pass-through to domestic prices for all combinations of the remaining parameters. The right side of the table shows that in every case greater monetary emphasis on stabilizing inflation succeeds in reducing the standard deviation of inflation. The third column shows that increasing the monetary response to output deviations tends to reduce pass-through in most cases but the size of this effect is relatively small. Moreover, in every row the pass-through coefficient moves in the same direction as the standard deviation of inflation. If responding more strongly to output deviations helps to stabilize inflation then it also reduces exchange rate pass-through. The fourth column shows that a faster monetary response tends to reduce passthrough, with little effect or a small decline, in the standard deviation of inflation. Altogether then, the Monte Carlo simulations confirm that changes in monetary policy rules that tend to stabilize inflation also tend to reduce pass-through.

\footnotetext{
${ }^{16}$ Varying the standard deviation of the policy shock never had any noticeable impact on pass-through.
} 
By comparing across rows, one can see that changes in model parameters other than the monetary policy parameters also affect the pass-through coefficients. The second row shows that increasing the effect of the real exchange rate on aggregate demand, $\alpha$, tends to increase pass-through because it strengthens one of the channels linking exchange rates to inflation. The third row shows that decreasing the interest sensitivity of aggregate demand, $\beta$, tends to increase pass-through by weakening one of the channels through which monetary policy can counteract exchange rate movements. The fourth row shows that increasing the responsiveness of inflation to output, $\gamma$, tends to increase pass-through by amplifying one of the channels by which exchange rates affect inflation. The fifth row shows that an increase in the direct pass-through parameter, $\phi$, tends to increase overall pass-through.

The remaining rows display the implications for pass-through of shutting down each stochastic shock individually. Eliminating the shocks to aggregate demand has only a small effect on pass-through. Eliminating the shocks to domestic costs decrease pass-through. Eliminating the markup shock in consumer prices increases pass-through moderately because it eliminates a disturbance that is uncorrelated with exchange rates. Finally, eliminating the shock to the exchange rate risk premium raises pass-through tremendously. This result reflects the important role of exchange rate variability in our results. Empirically, exchange rates are by far the most volatile macro time series in our model and numerous studies have confirmed the apparent exogeneity of exchange rates with respect to macroeconomic fundamentals. Once the exogenous component of the exchange rate is shut down, exchange rates tend to move nearly one-for-one with domestic prices. (Recall that foreign prices have been normalized at zero.) 


\section{Evidence}

We now turn to the empirical tests of our model. We begin with cross-country analysis estimating rates of pass-through for individual countries over our entire sample period, which spans 1971:Q1 to 2003:Q4. ${ }^{17}$ Then we regress these rates of pass-through on the mean and standard deviation of inflation for each country as a way of capturing a link between the inflation environment and the rate of pass-through. To implement a more direct test of the role of monetary policy, we estimate forward-looking Taylor-type policy rules for each of our countries and regress the pass-through coefficients on the estimated parameters of the monetary policy rules.

Casual inspection of the inflation data (see Figure 1) reveals that inflation in most of our countries underwent one or more regime breaks during the sample period. In order to utilize the inter-temporal information in the data as a robustness check on the cross-section results, we repeated both stages of the above analysis using changes in pass-through coefficients, inflation statistics, and policy rules estimated from two sub-samples of the data for each country. For most countries, the first sub-sample period is a period of relatively high and variable inflation whereas the second sub-sample has lower and more stable inflation. The extent of the differences between sub-samples differs across countries. The sample break is chosen independently for each country and is documented in Appendix A. The vertical lines in Figure 1 represent the dates where the samples are split. For the United States, the United Kingdom, Germany, and Japan we choose break dates in 1980 or 1981 for reasons described in Clarida,

\footnotetext{
${ }^{17}$ Due to limited data, the U.K. sample begins in 1975:Q3. Data sources are described in Appendix A.
} 
Gali and Gertler (1998). ${ }^{18}$ Canada and a number of smaller countries (Austria, Finland, Ireland, Netherlands, and Switzerland) appear to have followed the lead of these larger countries by the end of 1984. Another group of countries (Belgium, France, Italy, Portugal, and Spain) apparently switched regimes at the beginning of 1987, around the time of the last major EMS realignment. For Australia, New Zealand and Sweden we break the samples at the onset of their inflation targeting regime in the early 1990s. Finally, Greece joined the low-inflation bandwagon last-at the end of 1993 by our guess.

\section{III.A. Pass-Through in Industrial Countries}

For each country, we estimate the following pass-through equation:

$$
\Delta p=\delta_{0}+\delta_{1} \Delta p_{t-1}+\delta_{2} \Delta\left(e_{1}+p_{t}^{*}\right)+\delta_{3} \Delta\left(e_{t-1}+p_{t-1}^{*}\right)+\delta_{4} \Delta\left(e_{t-2}+p_{t-2}^{*}\right)
$$

The variables $p, e$, and $p^{*}$ are the quarterly consumer price index, trade-weighted exchange rate, and trade-weighted foreign consumer price index, respectively. All variables are seasonally adjusted. We also include dummy variables in some countries to control for changes in indirect taxes that affect consumer prices. ${ }^{19}$ The coefficients $\delta_{2}, \delta_{3}$, and $\delta_{4}$ represent the immediate, one-

${ }^{18}$ These breaks were chosen to follow closely the election of Margaret Thatcher in the United Kingdom, the appointment of Paul Volcker in the United States, the entry of Germany into the European Monetary System, and the adoption of substantial financial market deregulation in Japan.

${ }^{19}$ The dates of the tax dummies are listed in Appendix A. 
quarter lag and two-quarter lag impact of an exchange rate change or foreign price level change on the consumer price level, respectively. The equation incorporates lagged adjustment of inflation to shocks, so that $\left(\delta_{2}+\delta_{3}+\delta_{4}\right) /\left(1-\delta_{1}\right)$ measures the long-run pass-through of exchange rate movements to overall inflation.

In theory there may be an endogeneity problem with our estimation equation, in that changes in prices may affect future changes in the exchange rate, which would not be captured by equation (7). Empirically, researchers have found that standard macroeconomic variables have little ability to explain or predict exchange rates (e.g., the seminal paper by Meese and Rogoff (1983)). As a further check on the robustness of our conclusions, we reproduce all the results in the text using an alternative measure of the relationship between exchange rate movements and CPI inflation that allows for simultaneity, namely the long-run correlation derived from a bivariate vector autoregression, which is presented in Appendix B. As shown there, the results are very close to what we report below.

Table 4 reports for each country regression the long-run rates of pass-through and standard errors for the three estimation periods: the entire sample and the two sub-samples. ${ }^{20}$ These estimates are analogues to the rate of pass-through reported in the theoretical simulations. The average long-run rate of pass-through for the entire sample period is 0.23 , suggesting that on average a one percent depreciation in the local currency causes consumer prices to rise by

\footnotetext{
${ }^{20} \mathrm{Q}$ and $\mathrm{LM}$ tests, with lags from one to four quarters, do not reject the null of no autocorrelation for most countries. Our empirical specification maintains the assumption that inflation rates and changes in exchange-rate-adjusted foreign prices are both stationary variables. Augmented Dickey-Fuller tests (using four lags) reject nonstationarity of the change in exchange-rate-adjusted foreign price for every country in all sample periods. The same tests on domestic inflation rates reject nonstationarity in the full sample for 15 of 20 countries, and in both sub-samples for 13 of 20 countries.
} 
approximately a quarter of a percent in the long run. Fourteen of the twenty countries' rates of pass-through are significantly different from zero. There is a wide dispersion of rates of passthrough across countries, ranging from near zero in Sweden to 0.52 in Greece. The average autoregressive coefficient, $\delta_{l}$, (not shown) is 0.7 , implying a relatively quick pass-through. The average $\mathrm{R}^{2}$ is 0.6 .

The results for the two sub-samples show that there has been a decline in the rate of passthrough in most countries. On average, the rate of pass-through fell from 0.16 in the first subsample to 0.05 in the second sub-sample. In half of these countries the rate of pass-through is significantly different between the two sample periods. For inflation targeters, the average rate of pass-through was slightly higher than that for the other countries in the first sub-sample but it fell below the average for the other countries in the second sub-sample, possibly indicating the effects of stricter monetary responsiveness to inflation.

Before proceeding further, it is instructive to compare the magnitude of the decline in pass-through measured here with that implied by Campa and Goldberg (2002), who estimate pass-through to import prices over the samples 1975-89 and 1975-99. They find that long-run pass-through declined in most OECD countries. However, it does not follow that the declines in pass-through to CPIs are solely attributable to the declines in pass-through to import prices. The average decline in the rate of import price pass-through from the short to the long sample in Campa and Goldberg was no more than 0.04 (and less under alternative specifications). The average change in pass-through to CPIs that we estimate is about three times as large. Moreover, any direct effect on pass-through into CPIs of a change in pass-through at the import price level 
would be further attenuated by the fact that even in the most open economies, many consumption goods are produced locally and non-tradable services represent the majority of consumption.

\section{III.B. Inflation Variability and Pass-Through in Industrial Countries}

As the monetary authority becomes more vigilant and credible at fighting inflation, the mean and standard deviation of inflation should fall. Thus, an indirect way of testing the relationship between monetary policy and the rate of pass-through is to examine the link between the rate of pass-through and the behavior of inflation.

Table 3 reports summary statistics on inflation for the entire sample period and the two sub-samples for each the twenty countries. The mean rate of inflation is lower in the second subsample for every country and the standard deviation is lower for every country but Germany. The magnitudes of these changes are not noticeably different on average between inflation targeters and other countries. The following cross-country regressions of the rates of passthrough (PT) on these inflation statistics for the full sample yield strongly significant relationships.

$$
\begin{aligned}
& P T=\underset{(0.06)}{0.03}+\underset{(0.01)}{0.03^{* * *}} \operatorname{Mean}(\Delta p), R^{2}=0.44 \\
& P T=\underset{(0.07)}{0.03}+\underset{(0.01)}{0.04^{* * *}} \operatorname{Std} \operatorname{Dev}(\Delta p), R^{2}=0.38
\end{aligned}
$$

$* * *$ indicates significant at the 99 percent confidence interval 
Due to collinearity between the mean and standard deviation of inflation, we only include one of the inflation statistics at a time. The results suggest that about one-third or more of crosscountry variation in pass-through can be attributed to the inflation environment. One potential alternative explanation of cross-country variation in the rates of pass-through is the share of imports in GDP; however, we find no statistical link between pass-through and the import share. Moreover, including import shares in the above regressions does not significantly affect any of the other coefficients.

Switching from the cross-country to the intertemporal information in the data, we regressed changes in pass-through coefficients across sub-samples on changes in the inflation statistics. Once again, there is a significant link, similar to that from the full-sample regressions. Pass-through falls as the average rate of inflation falls and/or the volatility of inflation declines.

$$
\Delta P T=\underset{(0.07)}{0.01}+\underset{(0.01)}{0.01} * \Delta \operatorname{Mean}(\Delta p), R^{2}=0.11
$$

$$
\Delta P T=\underset{(0.05)}{0.02}+\underset{(0.01)}{0.03 *} * \Delta \operatorname{Std} \operatorname{Dec}(\Delta p), R^{2}=0.21
$$

*** (**) indicates significant at the 99 (95) percent confidence interval

A simple way to summarize these results is to plot the change in the rate of pass-through against the change in the inflation statistics for each country. The top panel of Figure 2 plots the change in the long-run rate of pass-through in a given country on the y axis against the change in 
the mean rate of inflation on the $\mathrm{x}$ axis. The diagonal line represents the relationship estimated in the above regression. Our theory implies that the rate of pass-through falls (rises) as the mean rate of inflation declines (increases), so that country observations should lie in the shaded regions of the graph. This relationship holds for 18 of the 20 countries in the sample. Turning to the standard deviation of inflation, plotted in the bottom panel, the only outlier is Finland; Germany's rate of pass-through rose as did the standard deviation of German inflation.

These results are robust to the inclusion of more countries, including developing countries. Choudhri, Faruqee, and Hakura (2002), for example, examine the correlation of passthrough with the mean rate of inflation in a sample dominated by developing countries. As our results and theoretical model suggest, however, lower variability of inflation may be the more relevant factor behind lower rates of pass-through. But, given the strong empirical connection between mean rates and standard deviations of inflation, it is not surprising that pass-through is significantly correlated with both.

\section{III.C. Monetary Policy in Industrial Countries}

The evidence of the previous section is consistent with our hypothesis that monetary policy has an important effect on pass-through. However, Table 2 showed that other economic parameters can affect both inflation variability and pass-through. We believe that it is plausible

that changes in monetary policy are the primary factor behind the decline in inflation variability over the past three decades, not least because the public record of central bank statements in many countries indicates that there have been changes in objectives and/or procedures.

Nevertheless, this section develops a more direct test of the relationship between a monetary 
authority's emphasis on stabilizing inflation and the rate of pass-through. We start by estimating a policy rule similar to that of Clarida, Gali and Gertler (1998) for each country. The estimation is done on three sample periods: the entire sample and the split sample as before, allowing for a change in the parameters across the two sub-samples.

For each country, we estimate:

$$
i_{t}=\theta_{0}+\theta_{1} i_{t-1}+\theta_{2} E_{t} \Delta p_{t+4}+\theta_{3} E_{t} g a p_{t+4}
$$

where $i$ is the end-of-quarter nominal interest rate on the three-month Treasury bill, $p$ is the quarterly consumer price index, and gap is the output gap which is constructed as the difference between real GDP and an HP-filter of the GDP series (as an estimate of potential). ${ }^{21} E_{t} \Delta p_{t+4}$ is the expectation at date $t$ of the rate of inflation between date $t$ and date $t+4$. We estimate equation (10) by the method of instrumental variables, using lagged values of the interest rate, inflation and the output gap as instruments. ${ }^{22}$ The use of instrumental variables reflects the fact that the central bank must form an expectation of the rate of inflation four quarters ahead using current data.

The coefficient $\theta_{l}$ indicates the speed of monetary policy adjustment. The larger the value of $\theta_{1}$, the slower the speed of adjustment. The coefficient $\theta_{2}$ represents the immediate response of the monetary authority to inflation. The expression $\theta_{2} /\left(1-\theta_{1}\right)$ represents the long-run

\footnotetext{
${ }^{21}$ We include quarterly dummy variables to control for changes in indirect taxes that are included in consumer prices but are generally not targeted by central banks.

${ }^{22}$ Due to limited data on interest rates for Finland, New Zealand, Norway, Spain, Switzerland, and the United Kingdom, our sample for these countries begins in 1981:Q1, 1974:Q4, 1972:Q3, 1978:Q1, 1973:Q1, and 1976:Q2, respectively.
} 
response to inflation in the presence of slow adjustment $\left(\theta_{1}>0\right)$. Similarly, the long-run response of the monetary authority to the output gap is $\theta_{3} /\left(1-\theta_{1}\right)$.

Comparing our empirical equation to our theoretical model, the estimated long-run response of monetary policy to inflation, $\theta_{2} /\left(1-\theta_{1}\right)$, is comparable to $\mu /(1-\rho 5)$ in the theoretical model. Similarly, the long-run output gap coefficient we estimate is the empirical analogue to $\lambda /(1-\rho 5)$. The lagged interest rate coefficient, $\theta_{1}$, is equivalent to $\rho 5$ in our theoretical model. For a monetary authority that moves to put more emphasis on low inflation, we expect to find an increase in the estimated long-run inflation response and/or an increase in the speed of adjustment (small coefficient value for $\theta_{l}$ ). As discussed in Section II, the effect of the output gap coefficient on inflation stabilization and pass-through is ambiguous.

Table 5 reports the long-run monetary policy coefficient estimates and the speed of adjustment term for each country over the entire sample period. There is variation in the coefficients across countries, particularly in the output gap coefficients. The large coefficient standard errors indicate that most of these differences are not statistically significant. The autoregressive coefficient averages 0.9 , implying 30 percent of the long-run effect is transmitted within one year.

Simulations from our theoretical model indicate that an increase in the inflation coefficient or a faster response of monetary policy should decrease the rate of pass-through. Attempts to link these monetary policy estimates with the corresponding estimated rates of passthrough yield mixed results over the entire sample period (see equations (11.a) and (11.b)). ${ }^{23}$

${ }^{23}$ Because the regressors are themselves estimates (from Table 5) we weight the observations in equations (11a) and (11b) by the standard errors of the regressions in which each set of $\theta$ s was estimated. 
These cross-country regressions do not show a significant link between the long-run inflation coefficient and pass-through. However, they do find a statistically significant link between the speed of monetary policy adjustment and pass-through.

(11.a) $P T=\underset{(0.09)}{0.24 * *} \underset{(0.10)}{0.03} \frac{\theta_{2}}{1-\theta_{1}}$, Sigma $=0.31$

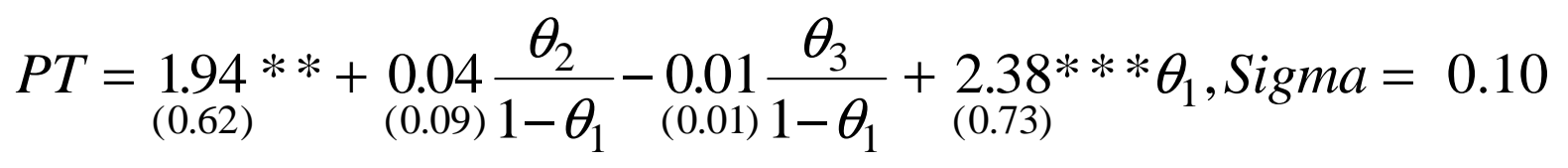

$* * *(* *)$ indicates significant at the $99(95)$ perent confidence interval)

If there have been important changes in monetary policy regimes during the sample, then the above regression analysis may not miss much of the link between pass-through and monetary policy. To address this problem, we estimate the monetary policy function separately in each sub-sample and regress changes in the rate of pass-through on changes in the policy coefficients.

Table 6 reports the estimated policy rule results for the two sub-samples. There are major differences between the sub-sample estimates. First, the average value of the long-run inflation coefficient rises from 0.9 in the first sub-sample to 2.5 in the second sub-sample. The increased coefficient value is apparent for both inflation targeters and other countries, although the inflation targeters' coefficients rise by a larger amount. Looking at the sub-samples, only the 
United States has an estimate significantly different from zero in the first sample period, but in the second sample period nearly half of the countries have significant inflation coefficients. Second, the long-run gap coefficients increase in value from the first to second subsample. However, the coefficients have large standard errors: notably the estimate for Portugal in the first sample period and Australia in the second. We do not place much emphasis on these values. Last, the speed of policy response falls (the lag coefficient rises) from the first to second subsamples.

In the second sub-sample most of the individual inflation coefficients are greater than the minimum of unity for a unique stable solution to our theoretical model (and none of them are significantly below unity). In the first sub-sample (as in the full sample) most of the inflation coefficients are below unity. We believe that our coefficients are biased downward partly because we use the volatile "headline" consumer price index instead of core domestic prices. ${ }^{24}$ We use the broad consumer price index because a consistent measure of core inflation is not available for many countries. Another source of downward bias may be a change in the monetary authority's inflation target within the sample. Even within our sub-samples it is possible that there were such shifts. For example, a monetary authority that pursued a strategy of "opportunistic disinflation" would appear to have a weak reaction to changes in inflation when inflation is falling, as it was in the United States during the 1990s ${ }^{25}$ Finally, the low monetary responses to inflation during the first sub-sample in many of these countries may be part of the

\footnotetext{
${ }^{24}$ In the United States, core inflation is typically defined using the CPI excluding food and energy.

${ }^{25}$ See Orphanides and Wilcox (1996).
} 
reason that they experienced great macroeconomic instability during the 1970s and 1980s. In other words, choosing a policy parameter that is associated with multiple or explosive solutions in the theoretical model may lead to instability in the real economy.

The implications of these changes in the policy rule coefficients across the subsamples on the value of pass-through are mixed. On the one hand, a slower speed of adjustment in the second sample period would tend to increase pass-through. But the higher long-run inflation coefficient tends to reduce pass-through. From Table 6 we see the magnitude of the change in the long-run inflation coefficient is much larger than that of the speed of adjustment term, suggesting that the long-run inflation effect may dominate and push pass-through down.

This hypothesis is confirmed in the weighted regressions based on changes across subsamples. $^{26}$

$$
\Delta P T=\underset{(0.03)}{-0.04}-\underset{(0.02)}{0.04} * \Delta \frac{\theta_{2}}{1-\theta_{1}}, \text { Sigma }=0.11
$$

$$
\Delta P T=\underset{(0.03)}{-0.05}-\underset{(0.01)}{0.03} * \Delta \frac{\theta_{2}}{1-\theta_{1}}-\underset{(0.01)}{0.01} * \Delta \frac{\theta_{3}}{1-\theta_{1}}+\underset{(0.16)}{0.21} \Delta \theta_{1}, \text { Sigma }=0.11
$$

**(*) indicataes significance at the $95(90) \%$ level.

\footnotetext{
${ }^{26}$ The country weights used in this regression are the averages of the standard errors of the policy rule regressions in the two subsamples.
} 
These equations suggest that as a monetary authority increases its emphasis on fighting inflation, which is depicted here as a positive value for $\theta_{2} /\left(1-\theta_{1}\right)$, that the rate of pass-through falls. This link is statistically significant in both regressions. The coefficient on the adjustment speed $\left(\theta_{1}\right)$ has the correct sign but is not significant. The output gap coefficient is significant but small. Based on the link between pass-through and these policy-rule estimates, the effect of the increased long-run emphasis on fighting inflation dominates the effect from a slower adjustment process, resulting in pass-through declining over time.

Figure 3 plots the changes in the inflation coefficients against the changes in the estimated rates of pass-through for each country. Our theoretical model implies that country observations should lie in the northwest or southeast quadrants (highlighted in the figure); passthrough falls (rises) as $\theta_{2} /\left(1-\theta_{1}\right)$ rises (falls). Seventeen of the twenty countries lie in these regions, with the Netherlands lying only slightly outside the region. The two outliers, Finland and Portugal, have very large standard errors on the long-run inflation coefficients in the policy rule (Table 6), suggesting that these observations should not be accorded much weight.

Our findings are consistent with a recent survey in the IMF's World Economic Outlook (May 2002) which looks at monetary policy in a low inflation era. The survey estimates monetary policy rules for Canada, Germany, the United Kingdom, and the United States. It finds that monetary policy in the 1980s and 1990s has been more responsive to changes in inflation than in the 1970s. It then argues that this period of low and stable inflation has had a significant effect on private sector behavior, such as a lengthening of wage contracts and a decline in pricing power of firms. These changes in behavior can contribute to the declines in the rates of pass-through we document. 
To check on the robustness of our results, we also estimated the policy rules and passthrough equations with alternative measures of potential output and with oil prices added to the models. The results are similar: an increased emphasis on inflation by a monetary authority may help to reduce the level of exchange rate pass-through.

\section{Conclusion}

This paper documents a decline in measured exchange rate pass-through at the macroeconomic level for many industrial countries since the 1980s. We develop a theoretical model to explain how such a development could be the consequence of a shift in the monetary authority's responsiveness to inflation. When agents expect the monetary authority to act strongly to stabilize the domestic inflation rate, they are less inclined to change prices in response to a given exchange rate shock. We present evidence for a sample of 20 industrial countries that supports this hypothesis indirectly and directly. First, we establish a robust and significant connection between pass-through behavior and inflation variability. This is an indirect test of the link between monetary policy and pass-through. Second, we uncover evidence connecting increased emphasis in monetary policy on stabilizing inflation with lower rates of pass-through. 


\section{References}

Bank of Canada. 2000. Monetary Policy Report, November. Ottawa.

Brayton, F, JM Roberts, and JC Williams. 1999. What's Happened to the Phillips Curve? Finance and Economics Discussion Series No. 1999-49. Board of Governors of the Federal Reserve System.

Campa, JM, and LS Goldberg. 2002. Exchange Rate Pass-Through into Import Prices: A Macro or Micro Phenomenon? Staff Report No. 149. Federal Reserve Bank of New York.

Choudhri, E, H Faruqee, and D Hakura. 2002. Explaining the Exchange Rate Pass-Through in Different Prices. Working Paper WP/02/224. International Monetary Fund.

Christiano, L, M Eichenbaum, and C Evans. 2001. Nominal Rigidities and the Dynamic Effects of a Shock to Monetary Policy. National Bureau of Economic Research Working Paper No. 8403.

Clarida, R, J Gali, and M Gertler. 1998. Monetary Policy Rules in Practice: Some International Evidence. European Economic Review 42: 1033-67.

Cunningham, A, and A Haldane. 1999. The Monetary Transmission Mechanism in the United Kingdom: Pass-Through and Policy Rules. manuscript. Bank of England.

Devereux, M, C Engel, and P Storgaard. 2003. Endogenous Exchange Rate Pass-Through When Nominal Prices Are Set in Advance. National Bureau of Economic Research Working Paper No. 9543.

Fair, RC. 2001. Actual Federal Reserve Policy Behavior and Interest Rate Rules. Federal Reserve Bank of New York Economic Policy Review 7: 61-71.

Freedman, C. 1994. The Use of Indicators and of the Monetary Conditions Index in Canada. in Baliño and Cottarelli (eds.) Frameworks for Monetary Stability: Policy Issues and Country Experiences. International Monetary Fund.

Freeman, RT, and JL Willis. 1995. Targeting Inflation in the 1990s: Recent Challenges. International Finance Discussion Papers No. 525. Board of Governors of the Federal Reserve System.

Froot, K, and R Thaler. 1990. Anomalies: Foreign Exchange. Journal of Economic Perspectives 4: 179-92.

Fuhrer, J, and G Moore. 1995. Inflation Persistence. Quarterly Journal of Economics 110: 12759. 
Goldberg, PK, and MM Knetter. 1997. Goods Prices and Exchange Rates: What Have We Learned? Journal of Economic Literature 35: 1243-72.

Goldfajn, I, and SR Werlang. 2000. The Pass-Through from Depreciation to Inflation: A Panel Study. Banco Central do Brasil Working Paper Series No. 5.

Leahy, M. 1998. New Sumary Measures of the Foreign Exchange Value of the Dollar. Federal Reserve Bulletin, 84: 811-818.

Parsley, D, and H Popper. 1998. Exchange Rates, Domestic Prices, and Central Bank Actions: Recent U.S. Experience. Southern Economic Journal 64: 957-72.

Hooper, P, K Johnson, and J Marquez. 2000. Trade Elasticities for the G-7 Countries. Princeton Studies in International Economics No. 87. Princeton University.

International Monetary Fund. 1996. World Economic Outlook, May. . 2002. World Economic Outlook, May.

Kamin, SB. 1998. A Multi-Country Comparison of the Linkages between Inflation and Exchange Rate Competitiveness. International Finance Discussion Papers No. 603. Board of Governors of the Federal Reserve System.

Laflèche, T. 1996. The Impact of Exchange Rate Movements on Consumer Prices. Bank of Canada Review Winter 1996-1997: 21-32.

Lubik, T, and F Schorfheide. 2004. Testing for Indeterminacy: An Application to U.S. Monetary Policy. American Economic Review 94: 190-217.

McCarthy, J. 2000. Pass-Through of Exchange Rates and Import Prices to Domestic Inflation in Some Industrialized Economies. Federal Reserve Bank of New York Staff Report 111.

Meese, R and K Rogoff. 1983. Empirical Exchange Rate Models of the Seventies: Do They Fit Out of Sample? Journal of International Economics 14: 3-24.

Nelson, E. 2000. UK Monetary Policy 1972-1997: A Guide Using Taylor Rules. manuscript ISSN 1368-5562. Bank of England.

Norambuena, CN. 2003. The Pass-Through from Depreciation to Inflation: Chile 1986-2001. Estudios de Economia 30: 133-55.

Olivei, GP. 2002. Exchange Rates and the Prices of Manufacturing Products Imported into the United States. New England Economic Review First Quarter: 3-18. Federal Reserve Bank of Boston. 
Orphanides, A, and DW Wilcox. 1996. The Opportunistic Approach to Disinflation. Finance and Economics Discussion Series No. 1996-24. Board of Governors of the Federal Reserve System.

Reifschneider, D, R Tetlow, and J Williams. 1999. Aggregate Disturbances, Monetary Policy, and the Macroeconomy: The FRB/US Perspective. Federal Reserve Bulletin 85: 1-19.

Taylor, JB. 1993. Discretion versus Policy Rules in Practice. Carnegie-Rochester Conference on Public Policy 39: 195-214.

2000. Low Inflation, Pass-Through, and the Pricing Power of Firms. European

Economic Review 44: 1389-1408.

Woodford, M. 2003. Interest and Prices: Foundations of a Theory of Monetary Policy. Princeton University Press: Princeton, NJ. 
Table 1 - Model and Data Sample Moments

\begin{tabular}{|lcccccccc|}
\hline \multicolumn{4}{|c}{} & \multicolumn{4}{c}{ Standard Deviation } \\
& $\mathrm{y}$ & $\Delta \mathrm{p}$ & $\mathrm{e}+\mathrm{p}^{*}-\mathrm{p}$ & $\mathrm{i}$ & $\Delta \mathrm{y}$ & $\Delta \mathrm{p}$ & $\Delta\left(\mathrm{e}+\mathrm{p}^{*}-\mathrm{p}\right)$ & $\Delta \mathrm{i}$ \\
\hline Model $^{*}$ & .79 & .32 & .91 & .90 & .95 & .53 & 3.60 & .84 \\
Data** & .76 & .38 & .91 & .91 & .84 & .53 & 3.54 & .82 \\
*Average over 10,000 Monte Carlo simulations using Base case parameters. \\
**Average over 20 industrial countries in the second sub-sample described in Section III of this paper.
\end{tabular}

Table 2 - Theoretical Model (Equations 1-6)

\begin{tabular}{|c|c|c|c|c|c|c|c|c|}
\hline & \multicolumn{4}{|c|}{$\underline{\text { Pass-Through Coefficient }}{ }^{*}$} & \multicolumn{4}{|c|}{$\underline{\text { Standard Deviation of Inflation }}$} \\
\hline & Base $^{* *}$ & $\mu=1.5$ & $\lambda=1.0$ & $\rho 5=0$ & Base $^{* *}$ & $\mu=1.5$ & $\lambda=1.0$ & $\rho 5=0$ \\
\hline Base & .11 & .18 & .11 & .09 & .15 & .19 & .16 & .15 \\
\hline$\alpha=.3$ & .25 & .50 & .24 & .21 & .17 & .24 & .17 & .17 \\
\hline$\beta=.5$ & .15 & .30 & .15 & .13 & .16 & .22 & .16 & .16 \\
\hline$\gamma=.02$ & .15 & .31 & .15 & .10 & .16 & .22 & .16 & .15 \\
\hline$\phi=.2$ & .25 & .30 & .25 & .24 & .27 & .29 & .27 & .27 \\
\hline$\sigma_{u}=0$ & .10 & .17 & .11 & .09 & .15 & .19 & .16 & .15 \\
\hline$\sigma_{v}=0$ & .90 & .96 & .93 & .85 & .13 & .15 & .14 & .13 \\
\hline$\sigma_{x}=0$ & .07 & .13 & .06 & .06 & .11 & .15 & .11 & .11 \\
\hline$\sigma_{z}=0$ & .14 & .24 & .13 & .10 & .13 & .17 & .13 & .12 \\
\hline
\end{tabular}


Table 3 - Long-run Rates of Pass-through

\begin{tabular}{|c|c|c|c|}
\hline & Entire Sample & First Sample & Second Sample \\
\hline Australia & $\begin{array}{c}0.14 \\
(0.07)\end{array}$ & $\begin{array}{c}0.09 \\
(0.08)\end{array}$ & $\begin{array}{c}0.01 \\
(0.04)\end{array}$ \\
\hline Austria & $\begin{array}{c}0.11 \\
(0.07)\end{array}$ & $\begin{array}{c}0.06 \\
(0.10)\end{array}$ & $\begin{array}{c}0.04 \\
(0.02)\end{array}$ \\
\hline Belgium & $\begin{array}{c}0.20 \\
(0.08) \\
\end{array}$ & $\begin{array}{c}0.21 \\
(0.09) \\
\end{array}$ & $\begin{array}{c}0.02 \\
(0.02) \\
\end{array}$ \\
\hline Canada & $\begin{array}{c}0.37 \\
(0.11)\end{array}$ & $\begin{array}{c}0.30 \\
(0.14)\end{array}$ & $\begin{array}{c}0.04 \\
(0.06)\end{array}$ \\
\hline Finland & $\begin{array}{c}0.01 \\
(0.14)\end{array}$ & $\begin{array}{l}-0.11 \\
(0.21)\end{array}$ & $\begin{array}{c}0.00 \\
(0.03)\end{array}$ \\
\hline France & $\begin{array}{c}0.23 \\
(0.12)\end{array}$ & $\begin{array}{c}0.17 \\
(0.07)\end{array}$ & $\begin{array}{c}0.01 \\
(0.03)\end{array}$ \\
\hline Germany & $\begin{array}{c}0.11 \\
(0.04)\end{array}$ & $\begin{array}{l}-0.13 \\
(0.11)\end{array}$ & $\begin{array}{c}0.12 \\
(0.03)\end{array}$ \\
\hline Greece & $\begin{array}{c}0.52 \\
(0.11)\end{array}$ & $\begin{array}{c}0.28 \\
(0.12)\end{array}$ & $\begin{array}{c}0.27 \\
(0.21)\end{array}$ \\
\hline Ireland & $\begin{array}{c}0.29 \\
(0.09) \\
\end{array}$ & $\begin{array}{c}0.18 \\
(0.11) \\
\end{array}$ & $\begin{array}{c}0.06 \\
(0.04) \\
\end{array}$ \\
\hline Italy & $\begin{array}{c}0.37 \\
(0.12) \\
\end{array}$ & $\begin{array}{c}0.33 \\
(0.09) \\
\end{array}$ & $\begin{array}{c}0.08 \\
(0.06) \\
\end{array}$ \\
\hline Japan & $\begin{array}{c}0.21 \\
(0.09)\end{array}$ & $\begin{array}{c}0.26 \\
(0.12) \\
\end{array}$ & $\begin{array}{c}0.02 \\
(0.02)\end{array}$ \\
\hline Netherlands & $\begin{array}{c}0.16 \\
(0.07)\end{array}$ & $\begin{array}{c}0.08 \\
(0.11)\end{array}$ & $\begin{array}{c}0.06 \\
(0.03)\end{array}$ \\
\hline New Zealand & $\begin{array}{c}0.42 \\
(0.10) \\
\end{array}$ & $\begin{array}{c}0.29 \\
(0.09) \\
\end{array}$ & $\begin{array}{c}0.01 \\
(0.05) \\
\end{array}$ \\
\hline Norway & $\begin{array}{c}0.28 \\
(0.15)\end{array}$ & $\begin{array}{c}0.11 \\
(0.17)\end{array}$ & $\begin{array}{l}-0.05 \\
(0.06)\end{array}$ \\
\hline Portugal & $\begin{array}{c}0.43 \\
(0.08) \\
\end{array}$ & $\begin{array}{c}0.37 \\
(0.08) \\
\end{array}$ & $\begin{array}{c}0.17 \\
(0.16) \\
\end{array}$ \\
\hline Spain & $\begin{array}{c}0.18 \\
(0.09) \\
\end{array}$ & $\begin{array}{c}0.14 \\
(0.07) \\
\end{array}$ & $\begin{array}{c}0.03 \\
(0.03) \\
\end{array}$ \\
\hline Sweden & $\begin{array}{c}0.02 \\
(0.07) \\
\end{array}$ & $\begin{array}{c}0.05 \\
(0.05) \\
\end{array}$ & $\begin{array}{c}0.02 \\
(0.02) \\
\end{array}$ \\
\hline Switzerland & $\begin{array}{c}0.15 \\
(0.09) \\
\end{array}$ & $\begin{array}{c}0.18 \\
(0.14)\end{array}$ & $\begin{array}{c}0.07 \\
(0.08) \\
\end{array}$ \\
\hline United Kingdom & $\begin{array}{c}0.15 \\
(0.05) \\
\end{array}$ & $\begin{array}{c}0.18 \\
(0.08) \\
\end{array}$ & $\begin{array}{c}0.08 \\
(0.05) \\
\end{array}$ \\
\hline United States & $\begin{array}{c}0.27 \\
(0.12) \\
\end{array}$ & $\begin{array}{c}0.19 \\
(0.36) \\
\end{array}$ & $\begin{array}{c}0.03 \\
(0.06) \\
\end{array}$ \\
\hline Average & 0.23 & 0.16 & 0.05 \\
\hline Inflation targeters & 0.22 & 0.18 & 0.03 \\
\hline Non-targeters & 0.23 & 0.15 & 0.06 \\
\hline
\end{tabular}

Standard errors in parenthesis. 
Table 4 - Inflation Statistics

\begin{tabular}{|l|c|c|c|c|c|c|}
\hline & \multicolumn{2}{|c|}{ Mean Rate of Inflation } & \multicolumn{2}{c|}{ Std. Deviation of Inflation } \\
\hline & $\begin{array}{c}\text { Entire } \\
\text { Sample }\end{array}$ & $\begin{array}{c}\text { First } \\
\text { Sample }\end{array}$ & $\begin{array}{c}\text { Second } \\
\text { Sample }\end{array}$ & $\begin{array}{c}\text { Entire } \\
\text { Sample }\end{array}$ & $\begin{array}{c}\text { First } \\
\text { Sample }\end{array}$ & $\begin{array}{c}\text { Second } \\
\text { Sample }\end{array}$ \\
\hline Australia & 6.63 & 8.60 & 2.59 & 5.06 & 4.78 & 2.65 \\
\hline Austria & 3.73 & 6.04 & 2.05 & 2.68 & 2.41 & 1.25 \\
\hline Belgium & 4.42 & 6.92 & 2.11 & 3.57 & 3.55 & 1.33 \\
\hline Canada & 5.13 & 8.34 & 2.81 & 3.73 & 2.99 & 2.16 \\
\hline Finland & 6.25 & 10.84 & 2.93 & 5.03 & 4.21 & 2.13 \\
\hline France & 5.54 & 9.25 & 2.10 & 4.48 & 3.72 & 1.16 \\
\hline Germany & 3.14 & 5.06 & 2.32 & 2.36 & 1.69 & 2.11 \\
\hline Greece & 13.50 & 17.17 & 5.17 & 8.82 & 8.01 & 2.98 \\
\hline Ireland & 7.67 & 14.00 & 3.10 & 7.23 & 7.16 & 1.77 \\
\hline Italy & 8.68 & 13.77 & 3.95 & 6.70 & 6.32 & 1.77 \\
\hline Japan & 3.49 & 9.19 & 1.08 & 5.60 & 7.11 & 1.90 \\
\hline Netherlands & 3.93 & 6.57 & 2.02 & 3.09 & 2.69 & 1.60 \\
\hline New Zealand & 7.73 & 11.87 & 2.01 & 6.75 & 5.96 & 1.78 \\
\hline Norway & 5.72 & 8.23 & 2.36 & 4.03 & 3.29 & 1.94 \\
\hline Portugal & 12.79 & 20.07 & 6.05 & 10.76 & 11.00 & 4.03 \\
\hline Spain & 8.96 & 14.07 & 4.22 & 6.63 & 6.06 & 2.02 \\
\hline Sweden & 5.91 & 8.10 & 1.58 & 4.75 & 4.14 & 2.22 \\
\hline Switzerland & 3.13 & 4.76 & 1.95 & 2.99 & 3.39 & 1.95 \\
\hline United Kingdom & 6.43 & 15.14 & 4.25 & 6.05 & 7.76 & 2.65 \\
\hline United States & 4.84 & 8.19 & 3.43 & 3.42 & 3.62 & 2.08 \\
\hline & & & & & & \\
\hline Average & 6.38 & 10.31 & 2.90 & 5.19 & 4.99 & 2.07 \\
\hline Inflation targeters & 6.37 & 10.41 & 2.65 & 5.27 & 5.12 & 2.29 \\
\hline Non-targeters & 6.39 & 10.28 & 2.99 & 5.16 & 4.95 & 2.00 \\
\hline
\end{tabular}


Table 5 - Policy Rule, Full sample

\begin{tabular}{|c|c|c|c|}
\hline & $\theta_{2} /\left(1-\theta_{1}\right)$ & $\theta_{3} /\left(1-\theta_{1}\right)$ & $\theta_{1}$ \\
\hline Australia & $\begin{array}{c}1.02 \\
(0.41)\end{array}$ & $\begin{array}{c}2.90 \\
(3.29)\end{array}$ & $\begin{array}{c}0.89 \\
(0.04)\end{array}$ \\
\hline Austria & $\begin{array}{c}0.79 \\
(0.38)\end{array}$ & $\begin{array}{l}-0.21 \\
(1.11)\end{array}$ & $\begin{array}{c}0.89 \\
(0.04)\end{array}$ \\
\hline \begin{tabular}{|l|} 
Belgium \\
\end{tabular} & $\begin{array}{c}1.06 \\
(0.62)\end{array}$ & $\begin{array}{c}3.69 \\
(5.64)\end{array}$ & $\begin{array}{c}0.93 \\
(0.05)\end{array}$ \\
\hline Canada & $\begin{array}{c}2.57 \\
(3.21)\end{array}$ & $\begin{array}{c}18.95 \\
(31.08)\end{array}$ & $\begin{array}{c}0.96 \\
(0.05)\end{array}$ \\
\hline Finland & $\begin{array}{c}1.38 \\
(0.83)\end{array}$ & $\begin{array}{c}1.89 \\
(2.06)\end{array}$ & $\begin{array}{c}0.91 \\
(0.06)\end{array}$ \\
\hline France & $\begin{array}{c}1.24 \\
(1.05)\end{array}$ & $\begin{array}{c}13.70 \\
(19.95)\end{array}$ & $\begin{array}{c}0.96 \\
(0.05)\end{array}$ \\
\hline Germany & $\begin{array}{c}1.38 \\
(0.37)\end{array}$ & $\begin{array}{c}1.62 \\
(0.93) \\
\end{array}$ & $\begin{array}{c}0.87 \\
(0.05) \\
\end{array}$ \\
\hline Greece & $\begin{array}{c}1.41 \\
(0.65)\end{array}$ & $\begin{array}{l}-0.41 \\
(1.70)\end{array}$ & $\begin{array}{c}0.97 \\
(0.02)\end{array}$ \\
\hline Ireland & $\begin{array}{c}0.59 \\
(0.35)\end{array}$ & $\begin{array}{c}2.91 \\
(2.77)\end{array}$ & $\begin{array}{c}0.90 \\
(0.05)\end{array}$ \\
\hline Italy & $\begin{array}{c}1.20 \\
(0.54)\end{array}$ & $\begin{array}{c}3.17 \\
(3.78)\end{array}$ & $\begin{array}{c}0.92 \\
(0.04)\end{array}$ \\
\hline Japan & $\begin{array}{c}1.05 \\
(0.23)\end{array}$ & $\begin{array}{c}0.50 \\
(1.56)\end{array}$ & $\begin{array}{c}0.88 \\
(0.03)\end{array}$ \\
\hline Netherlands & $\begin{array}{c}0.45 \\
(0.44)\end{array}$ & $\begin{array}{c}4.46 \\
(3.17)\end{array}$ & $\begin{array}{c}0.85 \\
(0.07) \\
\end{array}$ \\
\hline New Zealand & $\begin{array}{c}0.55 \\
(0.30)\end{array}$ & $\begin{array}{c}2.90 \\
(2.22)\end{array}$ & $\begin{array}{c}0.87 \\
(0.05) \\
\end{array}$ \\
\hline Norway & $\begin{array}{c}0.60 \\
(0.33)\end{array}$ & $\begin{array}{l}-0.96 \\
(1.04)\end{array}$ & $\begin{array}{c}0.86 \\
(0.05)\end{array}$ \\
\hline \begin{tabular}{|l} 
Portugal \\
\end{tabular} & $\begin{array}{c}1.04 \\
(0.56)\end{array}$ & $\begin{array}{l}-2.28 \\
(2.77)\end{array}$ & $\begin{array}{c}0.97 \\
(0.02)\end{array}$ \\
\hline Spain & $\begin{array}{c}0.89 \\
(0.26)\end{array}$ & $\begin{array}{c}1.35 \\
(2.06)\end{array}$ & $\begin{array}{c}0.82 \\
(0.06)\end{array}$ \\
\hline Sweden & $\begin{array}{c}0.66 \\
(0.30)\end{array}$ & $\begin{array}{l}-1.21 \\
(1.02)\end{array}$ & $\begin{array}{c}0.86 \\
(0.05)\end{array}$ \\
\hline Switzerland & $\begin{array}{c}0.61 \\
(0.43)\end{array}$ & $\begin{array}{c}2.45 \\
(1.57)\end{array}$ & $\begin{array}{c}0.87 \\
(0.06)\end{array}$ \\
\hline United Kingdom & $\begin{array}{c}1.03 \\
(0.61)\end{array}$ & $\begin{array}{c}4.42 \\
(6.19)\end{array}$ & $\begin{array}{c}0.94 \\
(0.06)\end{array}$ \\
\hline United States & $\begin{array}{c}0.93 \\
(0.37)\end{array}$ & $\begin{array}{c}1.13 \\
(1.39)\end{array}$ & $\begin{array}{c}0.86 \\
(0.06) \\
\end{array}$ \\
\hline Average & 1.02 & 3.05 & 0.90 \\
\hline Inflation targeters & 1.17 & 5.59 & 0.90 \\
\hline Non-targeters & 0.97 & 2.20 & 0.90 \\
\hline
\end{tabular}

Standard errors in parenthesis. 
Table 6 - Policy Rule, Sub-samples

\begin{tabular}{|c|c|c|c|c|c|c|}
\hline & \multicolumn{3}{|c|}{ First Sample } & \multicolumn{3}{|c|}{ Second Sample } \\
\hline & $\theta_{2} /\left(1-\theta_{1}\right)$ & $\theta_{3} /\left(1-\theta_{1}\right)$ & $\theta_{1}$ & $\theta_{2} /\left(1-\theta_{1}\right)$ & $\theta_{3} /\left(1-\theta_{1}\right)$ & $\theta_{1}$ \\
\hline Australia & $\begin{array}{c}0.72 \\
(0.57)\end{array}$ & $\begin{array}{c}2.22 \\
(2.89)\end{array}$ & $\begin{array}{c}0.86 \\
(0.06)\end{array}$ & $\begin{array}{c}4.84 \\
(14.52)\end{array}$ & $\begin{array}{l}-0.01 \\
(6.66)\end{array}$ & $\begin{array}{c}0.97 \\
(0.09)\end{array}$ \\
\hline Austria & $\begin{array}{c}0.24 \\
(0.70)\end{array}$ & $\begin{array}{l}-1.29 \\
(0.96)\end{array}$ & $\begin{array}{c}0.84 \\
(0.08)\end{array}$ & $\begin{array}{c}1.74 \\
(0.63)\end{array}$ & $\begin{array}{c}0.58 \\
(0.82)\end{array}$ & $\begin{array}{c}0.82 \\
(0.07)\end{array}$ \\
\hline Belgium & $\begin{array}{c}0.25 \\
(0.40) \\
\end{array}$ & $\begin{array}{l}-0.69 \\
(1.30) \\
\end{array}$ & $\begin{array}{c}0.83 \\
(0.08) \\
\end{array}$ & $\begin{array}{c}3.19 \\
(2.02) \\
\end{array}$ & $\begin{array}{c}1.61 \\
(2.79) \\
\end{array}$ & $\begin{array}{c}0.92 \\
(0.06) \\
\end{array}$ \\
\hline Canada & $\begin{array}{c}0.73 \\
(0.82) \\
\end{array}$ & $\begin{array}{c}0.46 \\
(1.95) \\
\end{array}$ & $\begin{array}{c}0.86 \\
(0.08) \\
\end{array}$ & $\begin{array}{c}2.13 \\
(0.95) \\
\end{array}$ & $\begin{array}{c}4.11 \\
(3.84) \\
\end{array}$ & $\begin{array}{c}0.91 \\
(0.06) \\
\end{array}$ \\
\hline Finland & $\begin{array}{l}-0.29 \\
(0.21)\end{array}$ & $\begin{array}{l}-1.25 \\
(0.61)\end{array}$ & $\begin{array}{c}0.12 \\
(0.22)\end{array}$ & $\begin{array}{c}0.88 \\
(4.88)\end{array}$ & $\begin{array}{c}3.91 \\
(9.66)\end{array}$ & $\begin{array}{c}0.96 \\
(0.08)\end{array}$ \\
\hline France & $\begin{array}{c}0.60 \\
(0.53)\end{array}$ & $\begin{array}{c}0.34 \\
(3.04) \\
\end{array}$ & $\begin{array}{c}0.87 \\
(0.08)\end{array}$ & $\begin{array}{c}3.04 \\
(1.64)\end{array}$ & $\begin{array}{c}2.77 \\
(3.95) \\
\end{array}$ & $\begin{array}{c}0.90 \\
(0.07)\end{array}$ \\
\hline Germany & $\begin{array}{c}3.21 \\
(1.67) \\
\end{array}$ & $\begin{array}{c}2.09 \\
(3.03) \\
\end{array}$ & $\begin{array}{c}0.84 \\
(0.16) \\
\end{array}$ & $\begin{array}{c}1.85 \\
(0.33) \\
\end{array}$ & $\begin{array}{l}-0.09 \\
(0.31) \\
\end{array}$ & $\begin{array}{c}0.78 \\
(0.09) \\
\end{array}$ \\
\hline Greece & $\begin{array}{l}-0.06 \\
(0.70)\end{array}$ & $\begin{array}{l}-1.14 \\
(2.20)\end{array}$ & $\begin{array}{c}0.97 \\
(0.02)\end{array}$ & $\begin{array}{c}0.58 \\
(0.72)\end{array}$ & $\begin{array}{l}-7.68 \\
(4.01)\end{array}$ & $\begin{array}{c}0.89 \\
(0.04)\end{array}$ \\
\hline Ireland & $\begin{array}{l}-0.27 \\
(0.35) \\
\end{array}$ & $\begin{array}{c}0.61 \\
(1.34) \\
\end{array}$ & $\begin{array}{c}0.83 \\
(0.09) \\
\end{array}$ & $\begin{array}{c}1.29 \\
(3.63) \\
\end{array}$ & $\begin{array}{c}3.55 \\
(3.86) \\
\end{array}$ & $\begin{array}{c}0.91 \\
(0.07)\end{array}$ \\
\hline Italy & $\begin{array}{c}0.75 \\
(0.72) \\
\end{array}$ & $\begin{array}{l}-1.15 \\
(1.31) \\
\end{array}$ & $\begin{array}{c}0.85 \\
(0.09) \\
\end{array}$ & $\begin{array}{c}2.67 \\
(0.51) \\
\end{array}$ & $\begin{array}{l}-0.20 \\
(2.65) \\
\end{array}$ & $\begin{array}{c}0.76 \\
(0.16) \\
\end{array}$ \\
\hline Japan & $\begin{array}{c}2.16 \\
(4.52)\end{array}$ & $\begin{array}{c}5.25 \\
(14.92)\end{array}$ & $\begin{array}{c}0.92 \\
(0.15)\end{array}$ & $\begin{array}{c}2.16 \\
(0.53)\end{array}$ & $\begin{array}{c}1.06 \\
(1.07)\end{array}$ & $\begin{array}{c}0.91 \\
(0.04)\end{array}$ \\
\hline Netherlands & $\begin{array}{c}0.27 \\
(0.41)\end{array}$ & $\begin{array}{c}0.70 \\
(1.02) \\
\end{array}$ & $\begin{array}{c}0.66 \\
(0.13) \\
\end{array}$ & $\begin{array}{l}-3.08 \\
(4.63)\end{array}$ & $\begin{array}{c}9.15 \\
(11.54) \\
\end{array}$ & $\begin{array}{c}0.98 \\
(0.03) \\
\end{array}$ \\
\hline New Zealand & $\begin{array}{l}-0.37 \\
(0.49) \\
\end{array}$ & $\begin{array}{l}-0.04 \\
(1.36) \\
\end{array}$ & $\begin{array}{c}0.76 \\
(0.08) \\
\end{array}$ & $\begin{array}{c}8.21 \\
(8.70) \\
\end{array}$ & $\begin{array}{l}-1.94 \\
(2.11) \\
\end{array}$ & $\begin{array}{c}0.93 \\
(0.06) \\
\end{array}$ \\
\hline Norway & $\begin{array}{c}0.04 \\
(0.42) \\
\end{array}$ & $\begin{array}{c}0.16 \\
(0.50) \\
\end{array}$ & $\begin{array}{c}0.79 \\
(0.08) \\
\end{array}$ & $\begin{array}{l}10.00 \\
(8.22) \\
\end{array}$ & $\begin{array}{c}1.64 \\
(2.97) \\
\end{array}$ & $\begin{array}{c}0.85 \\
(0.09) \\
\end{array}$ \\
\hline Portugal & $\begin{array}{c}7.01 \\
(17.17) \\
\end{array}$ & $\begin{array}{l}-13.34 \\
(31.69) \\
\end{array}$ & $\begin{array}{c}0.99 \\
(0.03) \\
\end{array}$ & $\begin{array}{c}1.67 \\
(0.74)\end{array}$ & $\begin{array}{c}4.08 \\
(5.17) \\
\end{array}$ & $\begin{array}{c}0.94 \\
(0.05) \\
\end{array}$ \\
\hline Spain & $\begin{array}{c}0.67 \\
(0.34) \\
\end{array}$ & $\begin{array}{l}-2.41 \\
(2.15) \\
\end{array}$ & $\begin{array}{c}0.40 \\
(0.16) \\
\end{array}$ & $\begin{array}{c}3.81 \\
(0.67) \\
\end{array}$ & $\begin{array}{l}-1.34 \\
(1.30)\end{array}$ & $\begin{array}{c}0.77 \\
(0.09) \\
\end{array}$ \\
\hline Sweden & $\begin{array}{c}0.09 \\
(0.59) \\
\end{array}$ & $\begin{array}{l}-0.93 \\
(0.83) \\
\end{array}$ & $\begin{array}{c}0.79 \\
(0.08) \\
\end{array}$ & $\begin{array}{c}0.65 \\
(1.15) \\
\end{array}$ & $\begin{array}{c}0.88 \\
(1.18) \\
\end{array}$ & $\begin{array}{r}0.89 \\
(0.05) \\
\end{array}$ \\
\hline Switzerland & $\begin{array}{c}0.52 \\
(0.56)\end{array}$ & $\begin{array}{c}1.16 \\
(1.61)\end{array}$ & $\begin{array}{c}0.79 \\
(0.14)\end{array}$ & $\begin{array}{c}0.54 \\
(1.97)\end{array}$ & $\begin{array}{c}2.71 \\
(5.78)\end{array}$ & $\begin{array}{c}0.95 \\
(0.08)\end{array}$ \\
\hline United Kingdom & $\begin{array}{c}0.87 \\
(0.61) \\
\end{array}$ & $\begin{array}{l}-0.53 \\
(0.93) \\
\end{array}$ & $\begin{array}{c}0.63 \\
(0.31) \\
\end{array}$ & $\begin{array}{c}1.76 \\
(0.33) \\
\end{array}$ & $\begin{array}{c}1.37 \\
(0.95) \\
\end{array}$ & $\begin{array}{c}0.83 \\
(0.06) \\
\end{array}$ \\
\hline United States & $\begin{array}{c}0.90 \\
(0.32) \\
\end{array}$ & $\begin{array}{l}-0.11 \\
(0.42) \\
\end{array}$ & $\begin{array}{c}0.52 \\
(0.18) \\
\end{array}$ & $\begin{array}{c}2.24 \\
(0.65) \\
\end{array}$ & $\begin{array}{c}0.73 \\
(0.76) \\
\end{array}$ & $\begin{array}{c}0.84 \\
(0.06) \\
\end{array}$ \\
\hline Average & 0.90 & -0.49 & 0.76 & 2.51 & 1.34 & 0.89 \\
\hline Inflation targeters & 0.41 & 0.24 & 0.78 & 3.52 & 0.88 & 0.91 \\
\hline Non-targeters & 1.07 & -0.74 & 0.75 & 2.17 & 1.50 & 0.88 \\
\hline
\end{tabular}

Standard errors in parenthesis. 


\section{Appendix A}

All data are available from authors upon request.

\section{$\Delta \mathbf{p}=$ quarterly domestic inflation}

Inflation is measured as the change in the consumer price index that the country's central bank targets (for the United Kingdom we use the RPIX). The original source of all the indexes are the national statistic office, seasonally adjusted at the source or by authors.

\section{$\Delta\left(e+p^{*}\right)=$ exchange-rate adjusted foreign consumer prices, quarterly rate}

This series is $\Delta$ (p/RER), where RER is the real exchange rate defined as foreign/domestic currency, and the price measures are the same as used in the inflation series. The real exchange rate is a seasonally adjusted trade-weighted measure that is constructed by the authors (except Greece, New Zealand and Norway which are OECD data). For a detailed discussion of the construction and trade weights see Leahy (1998).

$\mathbf{y}=$ output gap in percentage points, quarterly

The gap is (GDP-GDP*)/GDP*. GDP data are from International Financial Statistics, except Belgium, Greece, Ireland, Netherlands, New Zealand, and Portugal that come from Haver. GDP* is potential GDP, which we construct from a standard H-P filtering of the GDP series.

\section{i= nominal 3 month interest rate, annualized}

The measure and source varies by country as noted in the table.

\begin{tabular}{|c|c|c|c|c|c|}
\hline country & series & source & country & series & source \\
\hline Australia & $\begin{array}{l}\text { 3-month bank- } \\
\text { accepted bills }\end{array}$ & Haver & $\begin{array}{l}\text { Nether- } \\
\text { lands* }\end{array}$ & 3-month interbank rate & Haver \\
\hline \multirow[t]{2}{*}{ Austria* } & \multirow{2}{*}{$\begin{array}{l}\text { 3-month money } \\
\text { market rate } \\
\text { (3-month money } \\
\text { market rate) }\end{array}$} & \multirow{2}{*}{$\begin{array}{l}\text { Haver } \\
\text { (IFS) }\end{array}$} & & & \\
\hline & & & $\begin{array}{l}\text { New } \\
\text { Zealand }\end{array}$ & $\begin{array}{l}\text { 90-day bank bill rate } \\
\text { (90-day bank bill rate) }\end{array}$ & $\begin{array}{l}\text { Haver } \\
(\mathrm{OECD})\end{array}$ \\
\hline Belgium & $\begin{array}{l}\text { 3-month Treasury bill } \\
\text { rate }\end{array}$ & Haver & Norway & $\begin{array}{l}\text { 3-month money } \\
\text { market rate (NIBOR) }\end{array}$ & BIS \\
\hline \multirow{2}{*}{ Canada } & \multirow{2}{*}{$\begin{array}{l}\text { 3-month Treasury bill } \\
\text { rate }\end{array}$} & \multirow{2}{*}{ IFS } & & (Call inomey rate) & \\
\hline & & & \multirow[t]{2}{*}{ Portugal } & \multirow{2}{*}{$\begin{array}{l}\text { 3-month interbank rate } \\
\text { (3-month money } \\
\text { market rate) }\end{array}$} & \multirow{2}{*}{$\begin{array}{l}\text { Haver } \\
\text { (Haver) }\end{array}$} \\
\hline Finland* & $\begin{array}{l}\text { 3-month money } \\
\text { market rate }\end{array}$ & Haver & & & \\
\hline France* & Treasury bill rate & IFS & Spain & 3-month interbank rate & Haver \\
\hline Germany & $\begin{array}{l}\text { 3-month interbank rate } \\
\text { (FIBOR) }\end{array}$ & Haver & \multirow[t]{2}{*}{ Sweden } & \multirow{2}{*}{$\begin{array}{l}\text { 3-month Treasury bill } \\
\text { rate } \\
\text { (3-month Treasury } \\
\text { discount note rate) }\end{array}$} & \multirow[t]{2}{*}{$\begin{array}{l}\text { Bloomberg } \\
\text { (IFS) }\end{array}$} \\
\hline \multirow[t]{2}{*}{ Greece } & \multirow{2}{*}{$\begin{array}{l}\text { Commercial bank } \\
\text { deposit rate }\end{array}$} & \multirow{2}{*}{ IFS } & & & \\
\hline & & & \multirow{2}{*}{$\begin{array}{l}\text { Switzer- } \\
\text { land }\end{array}$} & \multirow{2}{*}{$\begin{array}{l}\text { 3-month Treasury bill } \\
\text { rate } \\
\text { (Call money rate) }\end{array}$} & \multirow{2}{*}{$\begin{array}{l}\text { IFS } \\
(\mathrm{OECD})\end{array}$} \\
\hline \multirow[t]{2}{*}{ Ireland } & \multirow{2}{*}{$\begin{array}{l}\text { 3-month interbank rate } \\
\text { (3-month money } \\
\text { market rate) }\end{array}$} & \multirow{2}{*}{$\begin{array}{l}\text { Haver } \\
\text { (Haver) }\end{array}$} & & & \\
\hline & & & U.K. & \multirow{2}{*}{$\begin{array}{l}\text { 3-month Treasury bill } \\
\text { average discount rate }\end{array}$} & Haver \\
\hline Italy & 3-month interbank rate & Haver & \multirow{2}{*}{ U.S. } & & \multirow{2}{*}{ IFS } \\
\hline Japan & 3-month Gensaki rate & Haver & & $\begin{array}{l}\text { 3-month Treasury bill } \\
\text { rate }\end{array}$ & \\
\hline
\end{tabular}

*3-month EURIBOR used for 1999:1 - 2003:4 (Haver).

Series and sources in parentheses used to estimate missing periods in primary data source. 


\section{Second Sample Period}

\begin{tabular}{|l|c|}
\hline country & period \\
\hline Australia & $1993: 2-2003: 4$ \\
\hline Austria & $1985: 1-2003: 4$ \\
\hline Belgium & $1987: 1-2003: 4$ \\
\hline Canada & $1985: 1-2003: 4$ \\
\hline Finland & $1985: 1-2003: 4$ \\
\hline France & $1987: 1-2003: 4$ \\
\hline Germany & $1981: 1-2003: 4$ \\
\hline Greece & $1994: 1-2003: 3$ \\
\hline Ireland & $1985: 1-2003: 4$ \\
\hline Italy & $1987: 1-2003: 4$ \\
\hline Japan & $1981: 1-2003: 4$ \\
\hline Netherlands & $1985: 1-2003: 4$ \\
\hline New Zealand & $1990: 2-2003: 3$ \\
\hline Norway & $1990: 1-2003: 3$ \\
\hline Portugal & $1987: 1-2003: 4$ \\
\hline Spain & $1987: 1-2003: 4$ \\
\hline Sweden & $1993: 1-2003: 4$ \\
\hline Switzerland & $1985: 1-2003: 4$ \\
\hline U.K. & $1981: 1-2003: 4$ \\
\hline U.S. & $1981: 1-2003: 4$ \\
\hline & \\
\hline
\end{tabular}


Individual Country Tax Dummies*

(Dummies for changes in tax policies)

\begin{tabular}{|l|l|}
\hline country & \multicolumn{1}{|c|}{ tax policy change } \\
\hline Australia & $2000: 3$ \\
\hline Austria & $1999: 1$ (policy only) \\
\hline Canada* & $1991: 1,1994: 1,1994: 2$ \\
\hline Finland & $1999: 1$ (policy only) \\
\hline Greece & $1994: 2$ (policy only), 1996:1 \\
\hline Japan & $1989: 2,1997: 2$ \\
\hline Netherlands & $1999: 1$ (policy only) \\
\hline Sweden & $1991: 1,1992: 1,1993: 1$ \\
\hline United Kingdom & $1979: 3$ \\
\hline
\end{tabular}

* All dummies set equal to one in the appropriate quarter, except Canada's 1994 VAT change that was phased in over two quarters so we set the dummy as 1994:1 $=2 / 3,1994: 2=1 / 3$. 


\section{Appendix B \\ Estimates of the Long-run Correlation}

In this appendix we provide an alternative methodology for estimating the relationship between movements in consumer prices and movements in exchange rates. Allowing for the possibility that there may be endogenity between inflation and exchange rate movements, here we estimate a bivariate vector autoregression between these two variables for each country and each sample period, and consider the long-run correlations from this analysis. The equation we estimate is:

$$
\Delta p_{t}=\gamma_{0}+\sum_{i=1}^{3} \gamma_{i} \Delta p_{t-i}+\sum_{j=0}^{3} \gamma_{j} \Delta\left(e_{t-j}+p_{t-j}^{*}\right)+\varepsilon_{t}
$$

$\Delta\left(e_{t}+p_{t}^{*}\right)=\beta_{0}+\sum_{i=1}^{3} \beta_{i} \Delta\left(e_{t-i}+p_{t-i}^{*}\right)+\sum_{j=0}^{3} \beta_{j} \Delta p_{t-i j}^{*}+\mu_{t}$

From these equations we back out the long-run covariance and variance of the two variables and calculate the long-run correlation. As shown below, these long-run correlation estimates are correlated with the long-run pass-through estimates we use in the main text and the conclusions we draw from the long-run pass-through estimates are reproduced using the long-run correlation estimates, suggesting our results are robust to the issue of simultaneity between movements in consumer prices and movements in exchange rates.

Table B1 lists the estimated long-run correlations along with the long-run pass-through estimates. The average long-run correlation coefficient is 0.75 while the average long-run passthrough estimate is 0.23 . These two measures do not need to be similar in value. The long-run correlation estimate signals the strength of association between exchange rate movements and prices over the long run, and is independent of particular units of measurement; the long-run pass-through coefficient depends on the relative magnitudes of changes in the variables, as it indicates the quantity of the change in the exchange rate that feeds into the price level in the long run. The correlation between the two measures over the full sample is 0.68. Looking at the subsamples, the correlation between the two measures is higher in the first sample period than the second.

Table B1 - Estimates of long-run correlations and long-run pass-through (full sample)

\begin{tabular}{|l|l|l|}
\hline \multicolumn{1}{|c|}{ Country } & \multicolumn{2}{c|}{ Estimate of Long-run } \\
\hline & Correlation & Pass-through \\
\hline Australia & 0.751 & 0.144 \\
\hline Austria & 0.649 & 0.108 \\
\hline Belgium & 0.784 & 0.202 \\
\hline Canada & 0.763 & 0.371 \\
\hline Finland & 0.619 & 0.008 \\
\hline
\end{tabular}




\begin{tabular}{|l|l|l|}
\hline France & 0.911 & 0.229 \\
\hline Germany & 0.674 & 0.110 \\
\hline Greece & 0.943 & 0.520 \\
\hline Ireland & 0.892 & 0.290 \\
\hline Italy & 0.869 & 0.366 \\
\hline Japan & 0.702 & 0.206 \\
\hline Netherlands & 0.767 & 0.156 \\
\hline New Zealand & 0.897 & 0.421 \\
\hline Norway & 0.865 & 0.276 \\
\hline Portugal & 0.900 & 0.435 \\
\hline Spain & 0.863 & 0.185 \\
\hline Sweden & 0.539 & 0.021 \\
\hline Switzerland & 0.349 & 0.151 \\
\hline U.K. & 0.417 & 0.152 \\
\hline U.S. & 0.759 & 0.268 \\
\hline Correlation & 0.68 & \\
\hline
\end{tabular}

Using the long-run correlation estimates in place of the long-run pass-through estimates, we rerun the weighted regressions in the text. We find that the long-run correlation between the rate of inflation and changes in exchange rates reacts almost identically to the inflation statistics as the long-run pass-through estimates reported in the text. For example, looking at the crosssection relationship between the long-run correlation estimate and inflation statistics over the entire sample, we find coefficient estimates similar in value and significance. That is, rerunning equations $8 \mathrm{a}$ and $8 \mathrm{~b}$ with the dependent variable replaced by the long-run correlation estimate, we find:

Corr $=\underset{(0.12)}{0.36^{* * * *}}+\underset{(0.02)}{0.04 * *} \operatorname{Mean}(\Delta \mathrm{p}), \mathrm{R}^{2}=0.20$

$\operatorname{Corr}=\underset{(0.13)}{0.33^{* * *}}+\underset{(0.02)}{0.06 * *} \operatorname{Std} \operatorname{Dev}(\Delta \mathrm{p}), \mathrm{R}^{2}=0.22$

$* * *(* *)$ indicates signficant at the $99(95)$ percent confidence interval 
Next equations $9 \mathrm{a}$ and $9 \mathrm{~b}$, which focus on changes across sub-samples, find similar results.

$$
\Delta \text { Corr }=\underset{(0.17)}{0.15}+\underset{(0.02)}{0.08^{* * * *}} \Delta \operatorname{Mean}(\Delta \mathrm{p}), \mathrm{R}^{2}=0.30
$$

$\Delta \operatorname{Corr}=\underset{(0.14)}{-0.12}+\underset{(0.03)}{0.07} \Delta \operatorname{Std} \operatorname{Dev}(\Delta \mathrm{p}), \mathrm{R}^{2}=0.04$

$* * *$ indicates signficant at the 99 percent confidence interval

There is a more significant link with changes in inflation than found in the text using the change in long-run pass-through, while the relationship between the long-run correlation and the standard deviation of inflation is weaker than what we found in the long-run pass-through regression. These results are suggestive that graphs similar to what is shown in Figure 2 would convey the same point, as they do.

Linking long-run correlations to monetary policy, similar in manner to equations 11 and 12 in the text, we find the data support our hypothesized link between increased emphasis on fighting inflation and reductions in the correlation between the rate of inflation and changes in the exchange rate. Actually, the weighted regressions that estimate the impact of a change in the long-run Policy rule inflation coefficient on the change in the correlation are more significant than what is found in the text.

$$
\begin{gathered}
\text { Corr }=\underset{(0.12)}{0.76 * * *}-\underset{(0.13)}{0.02} \frac{\theta_{2}}{1-\theta_{1}}, \text { Sigma }=0.39 \\
\text { Corr }=\underset{(0.90)}{-0.76}+\underset{(0.12)}{0.08} \frac{\theta_{2}}{1-\theta_{1}}-\underset{(0.01)}{0.01} \frac{\theta_{3}}{1-\theta_{1}}+\underset{(1.06)}{1.560} \theta_{1}, \text { Sigma }=0.14 \\
\Delta \text { Corr }=\underset{(0.10)}{0.08} \underset{(0.05)}{-0.18 * * *} \Delta \frac{\theta_{2}}{1-\theta_{1}}, \text { Sigma }=0.32 \\
\Delta \text { Corr }=\underset{(0.09)}{-0.02}-\underset{(0.02)}{0.06 * * \Delta} \frac{\theta_{2}}{1-\theta_{1}}-\underset{(0.02)}{0.03} \Delta \frac{\theta_{3}}{1-\theta_{1}}-\underset{(0.42)}{0.04} \Delta \theta_{1}, \text { Sigma }=0.28 \\
* *(* * *) \text { indicates significant at the } 95(99) \% \text { level. }
\end{gathered}
$$


Figure 1 - Inflation

Australia

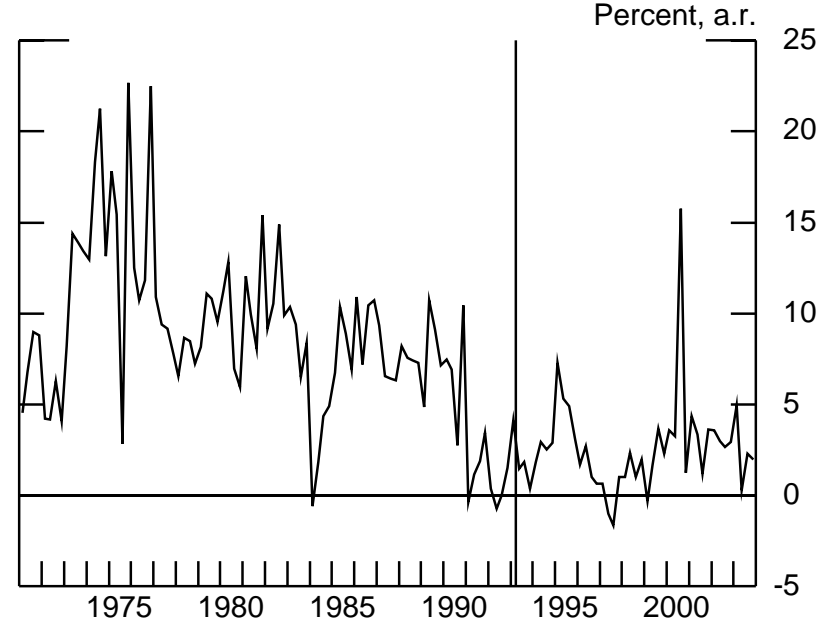

Belgium

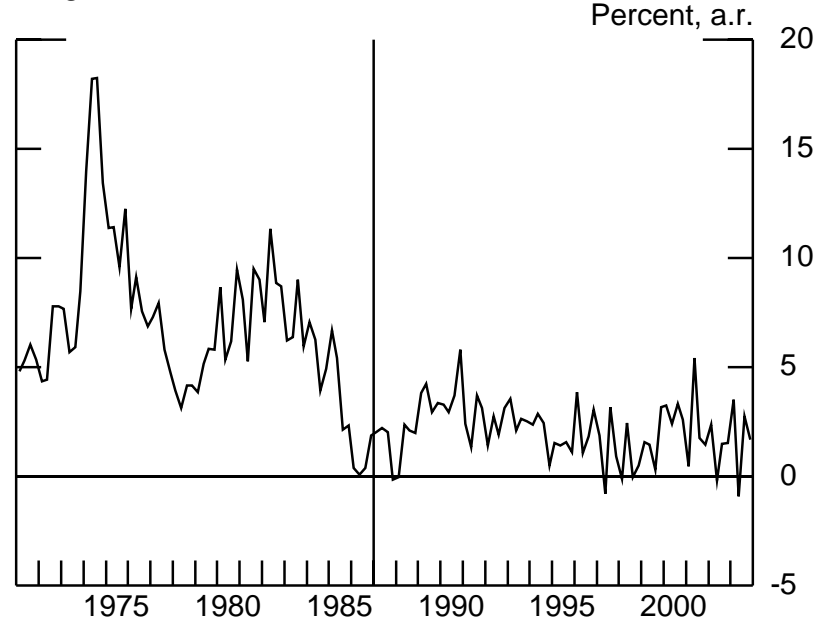

Finland

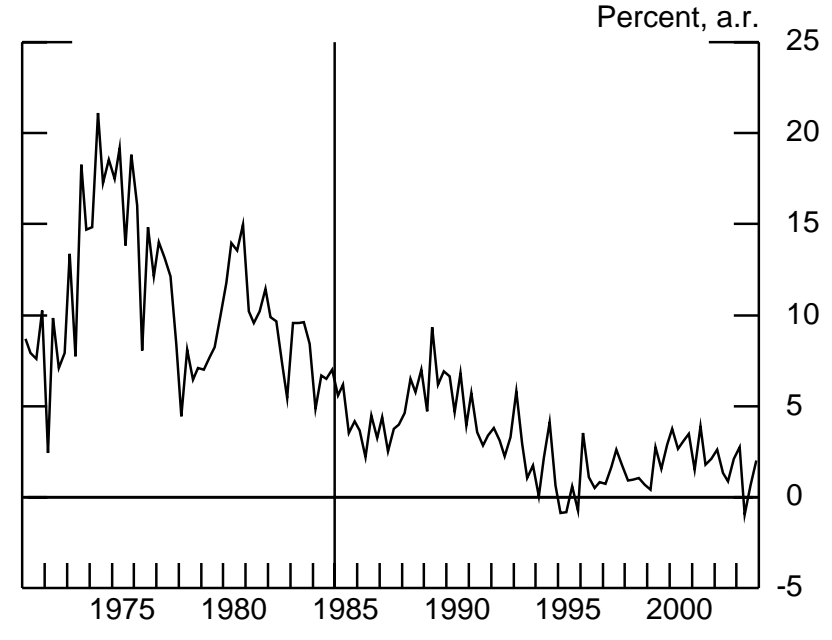

Austria

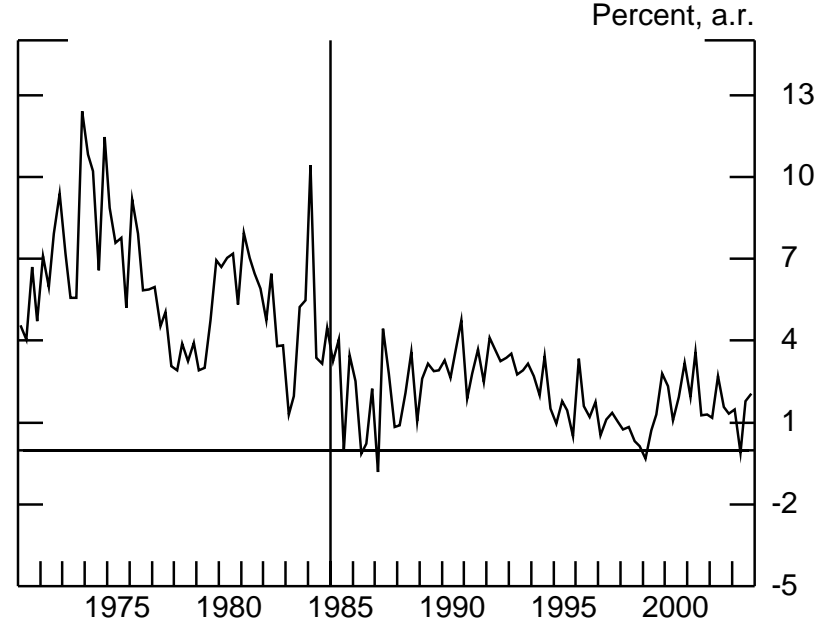

Canada

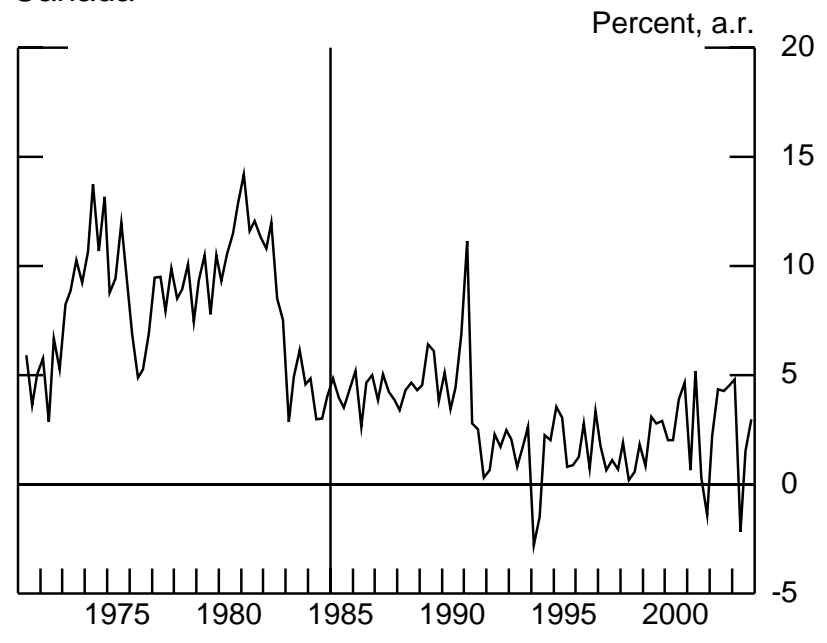

France

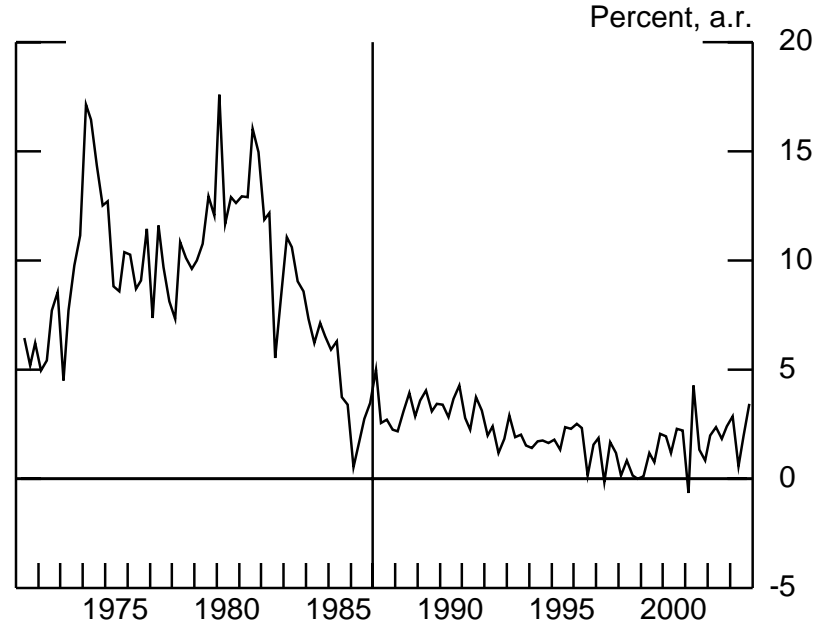



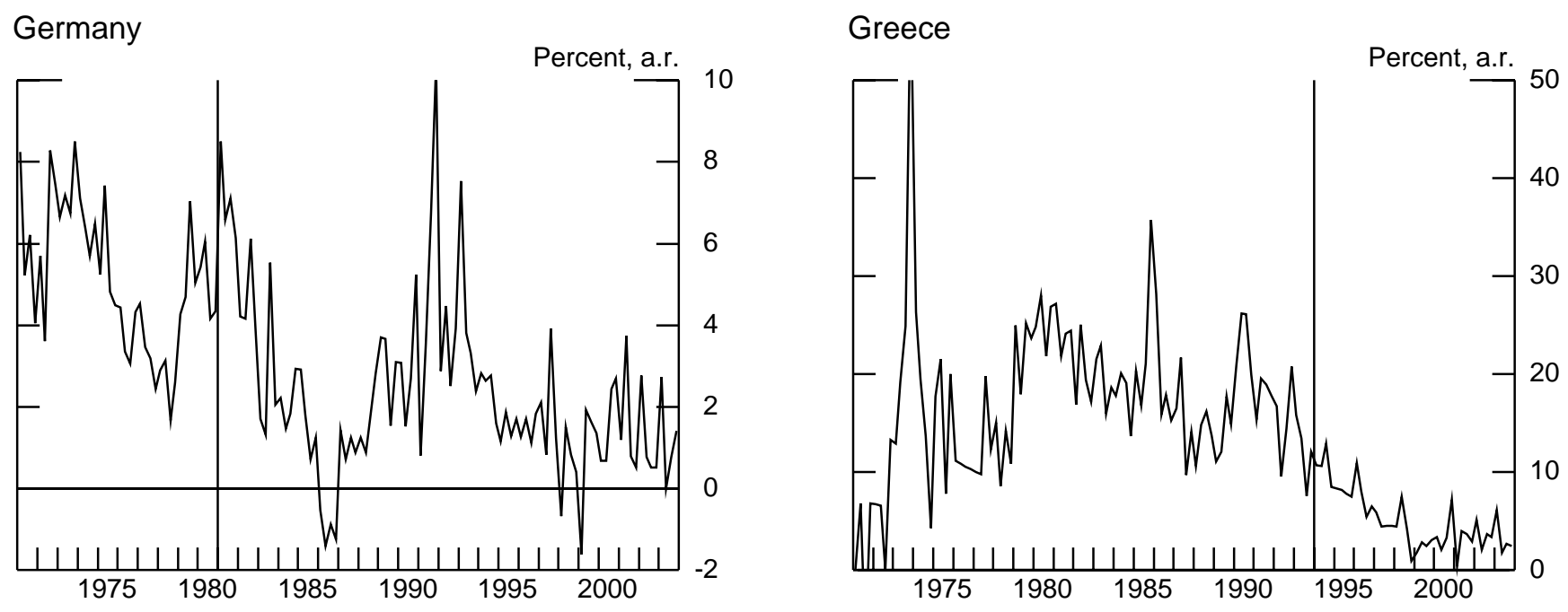

Ireland

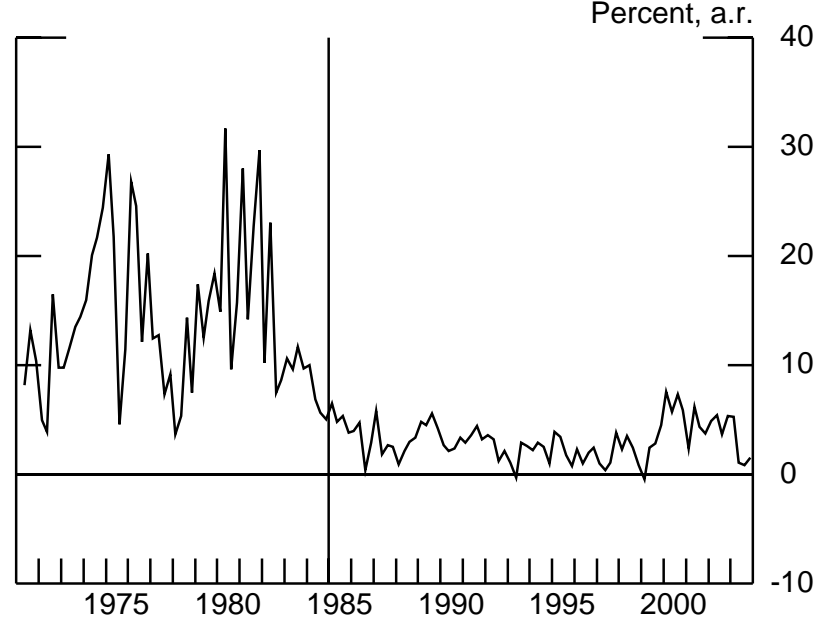

Japan

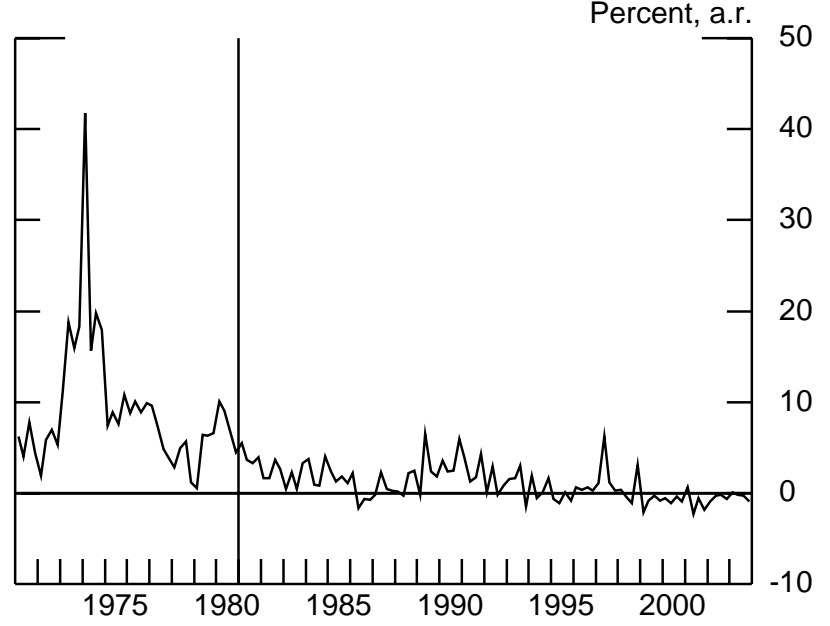

Italy

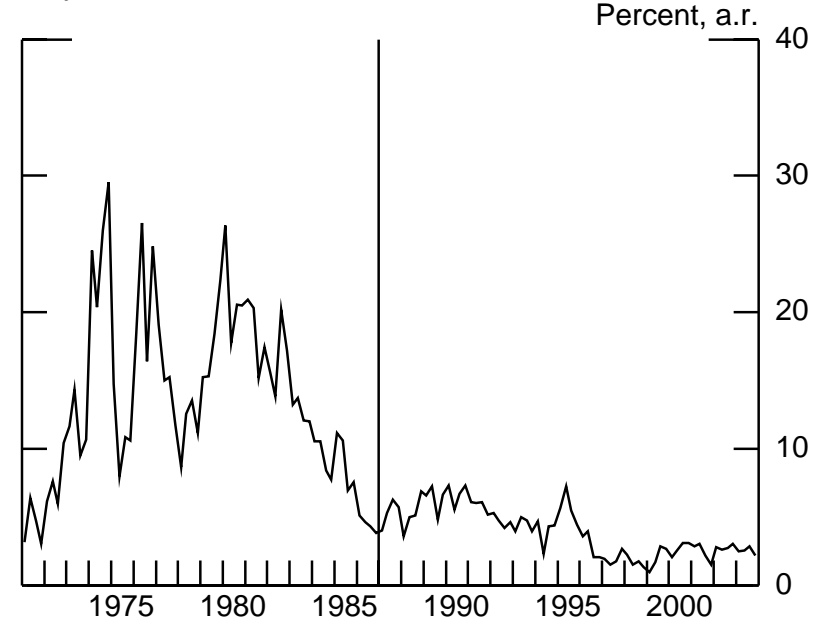

Netherlands

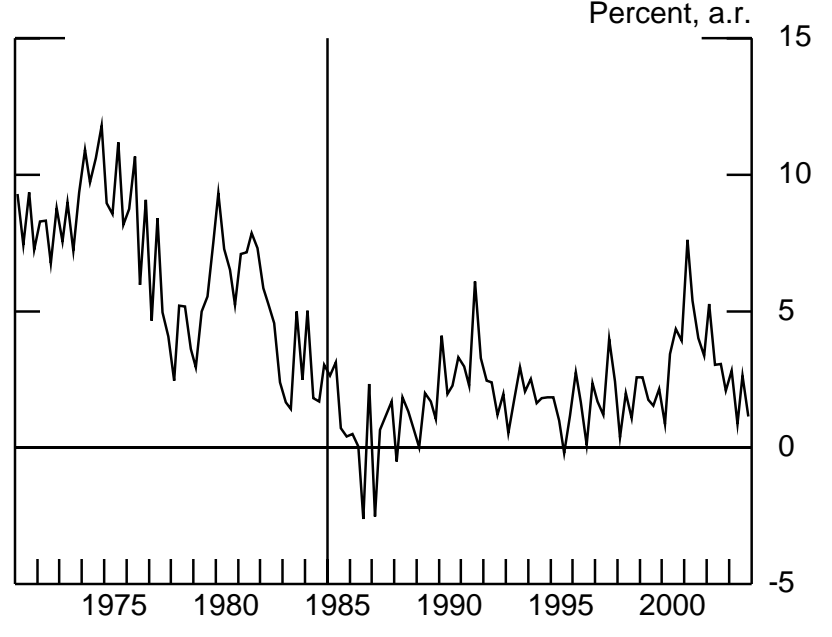


New Zealand

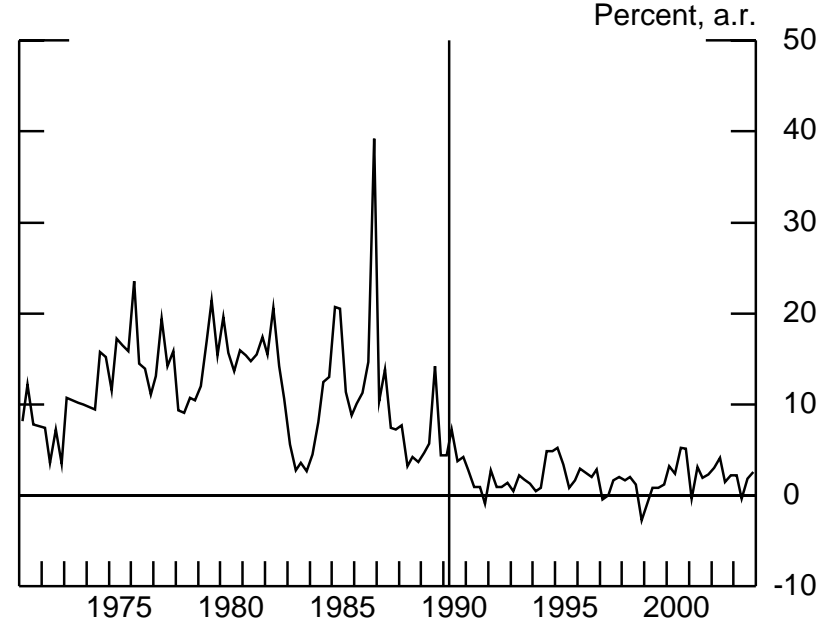

Portugal

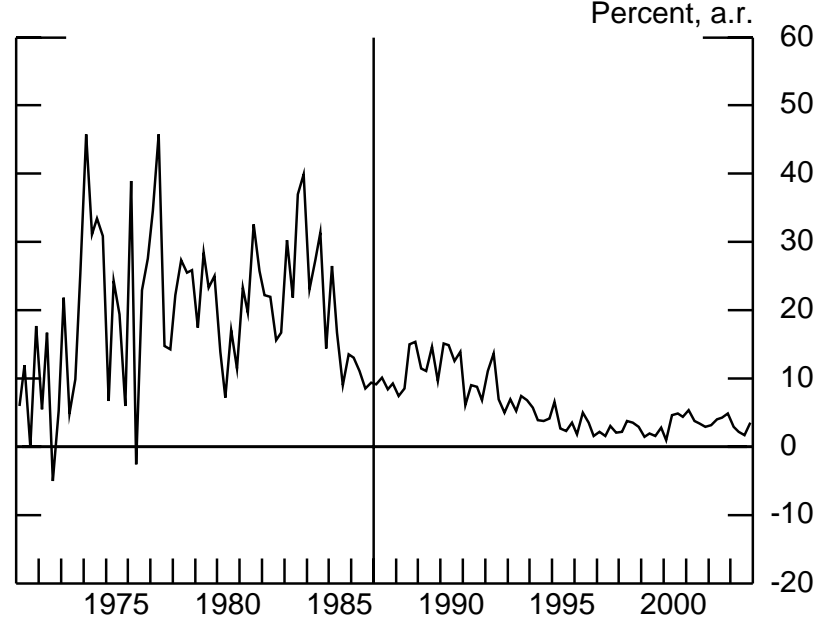

Sweden

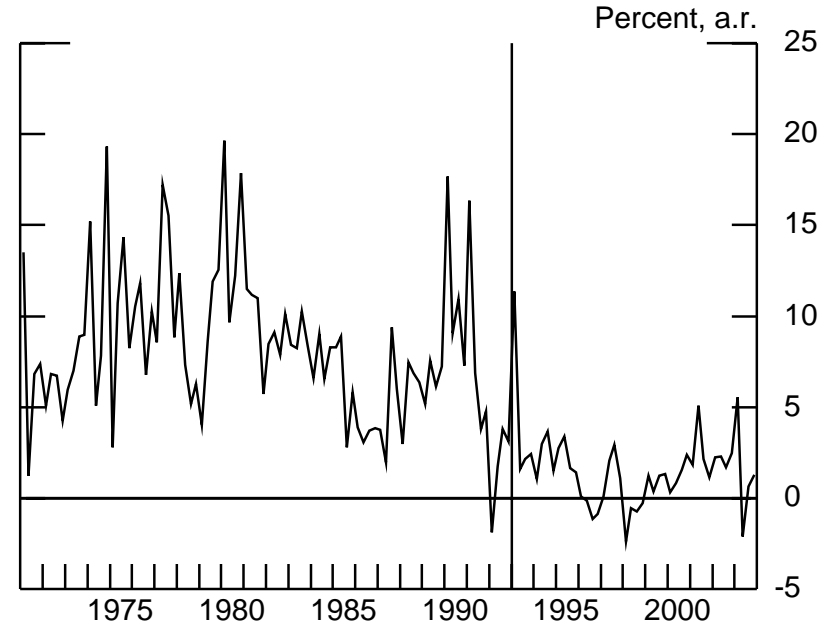

Norway

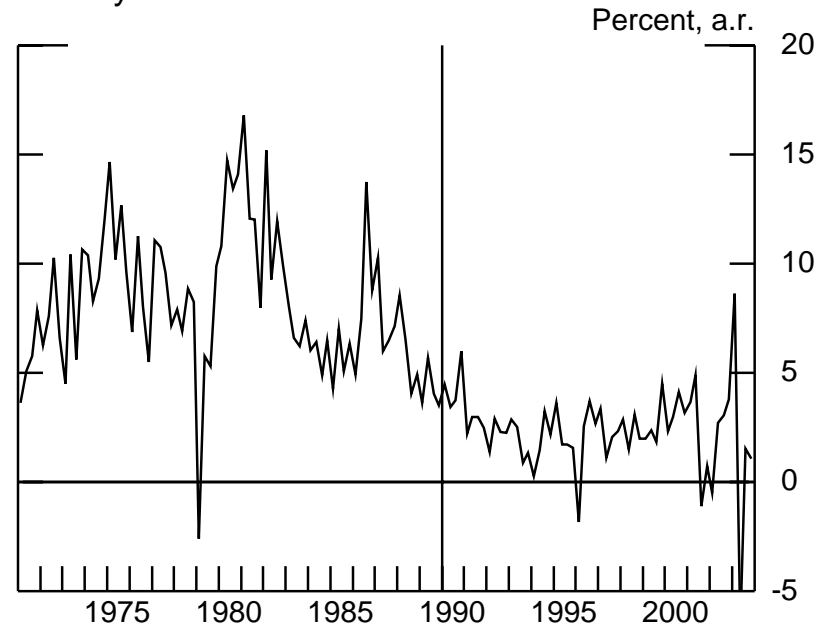

Spain

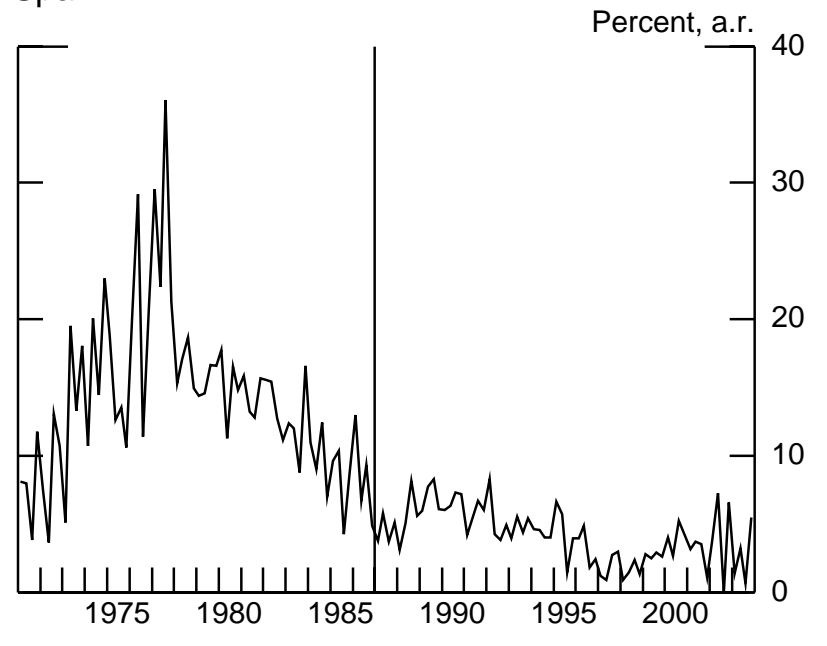

Switzerland

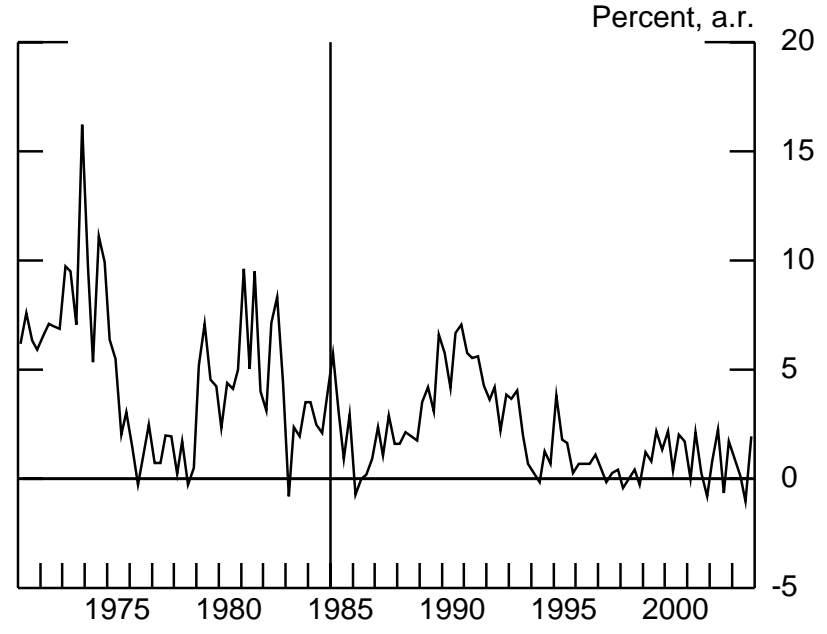


United Kingdom

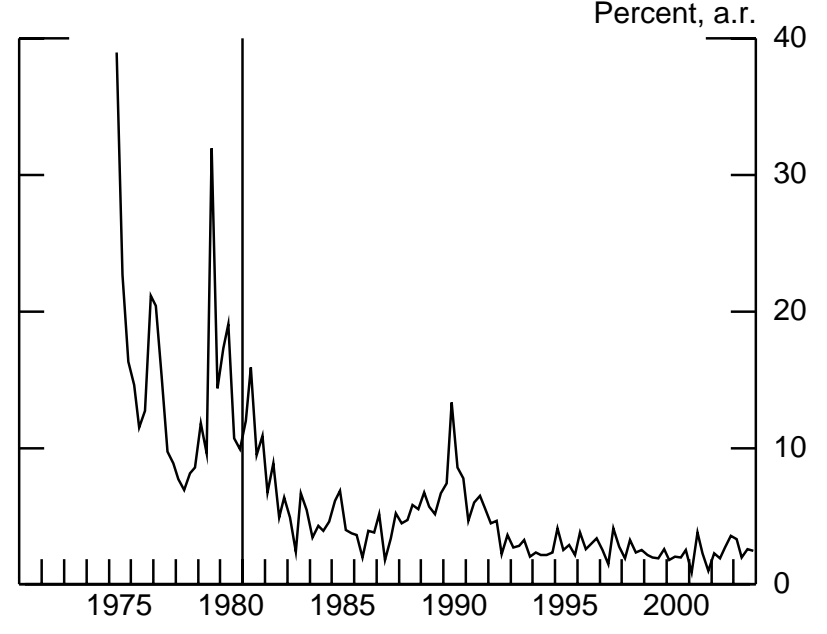

United States

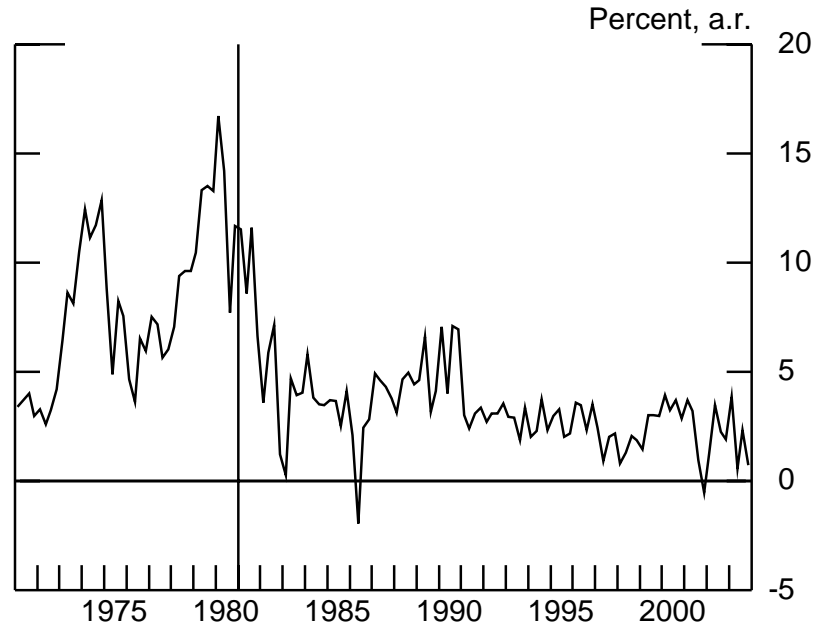


Figure 2 - Pass-through and Inflation Statistics

Pass-through coefficient vs. mean of inflation

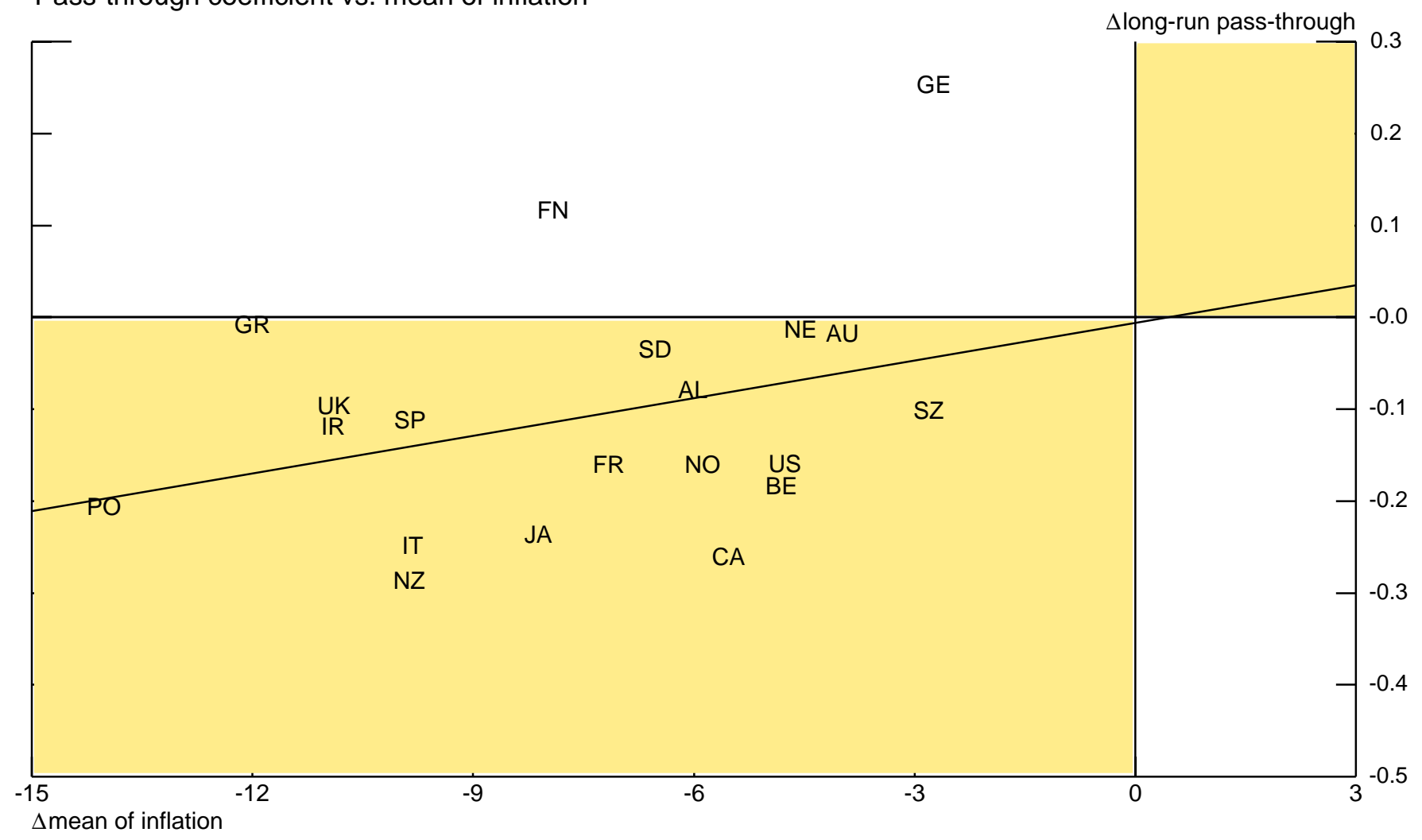

Pass-through coefficient vs. std. dev. of inflation

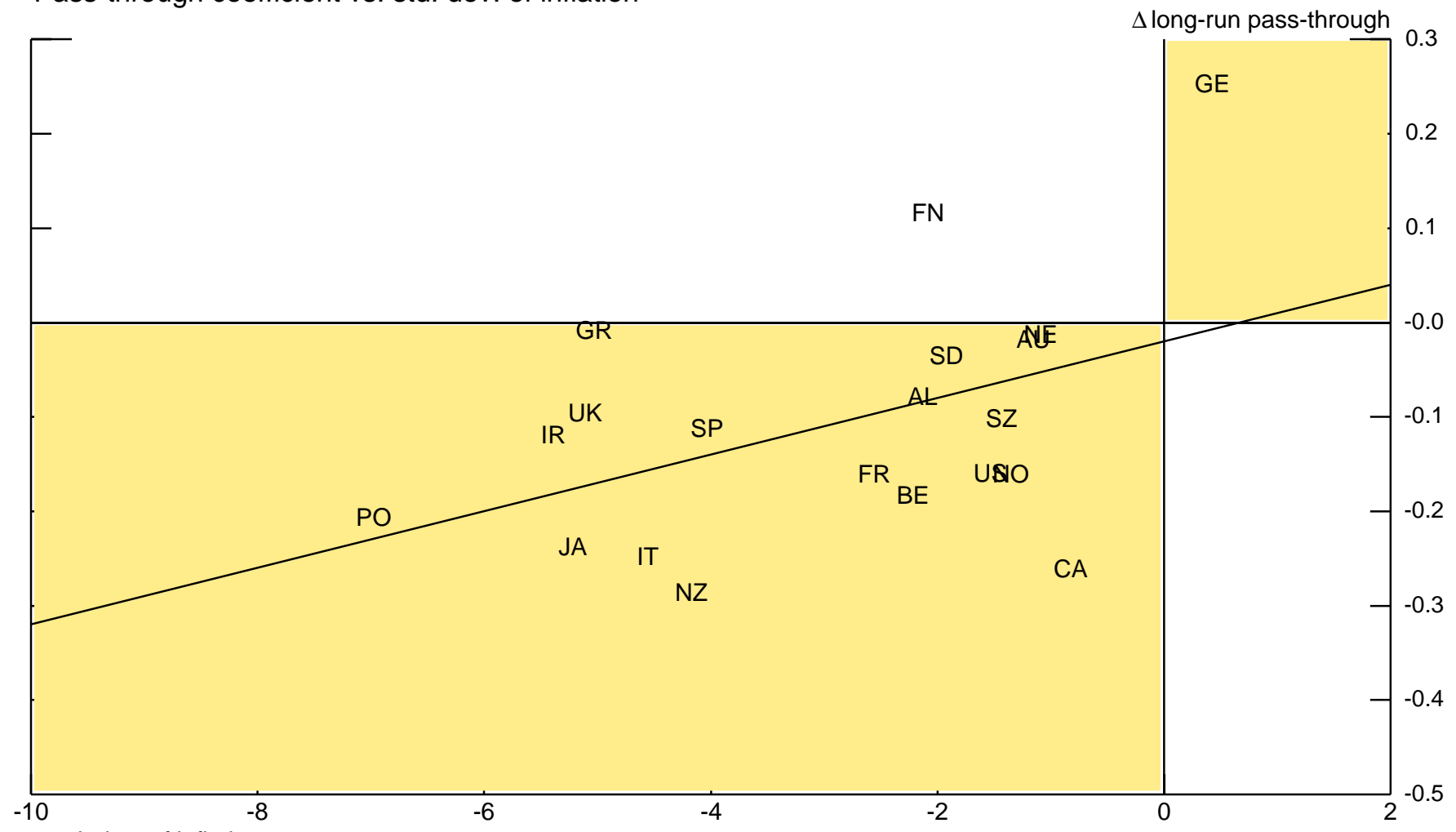

$\Delta$ std. dev. of inflation 
Figure 3 - Pass-through and Monetary Policy

Pass-through coefficient vs. long-run inflation coefficient

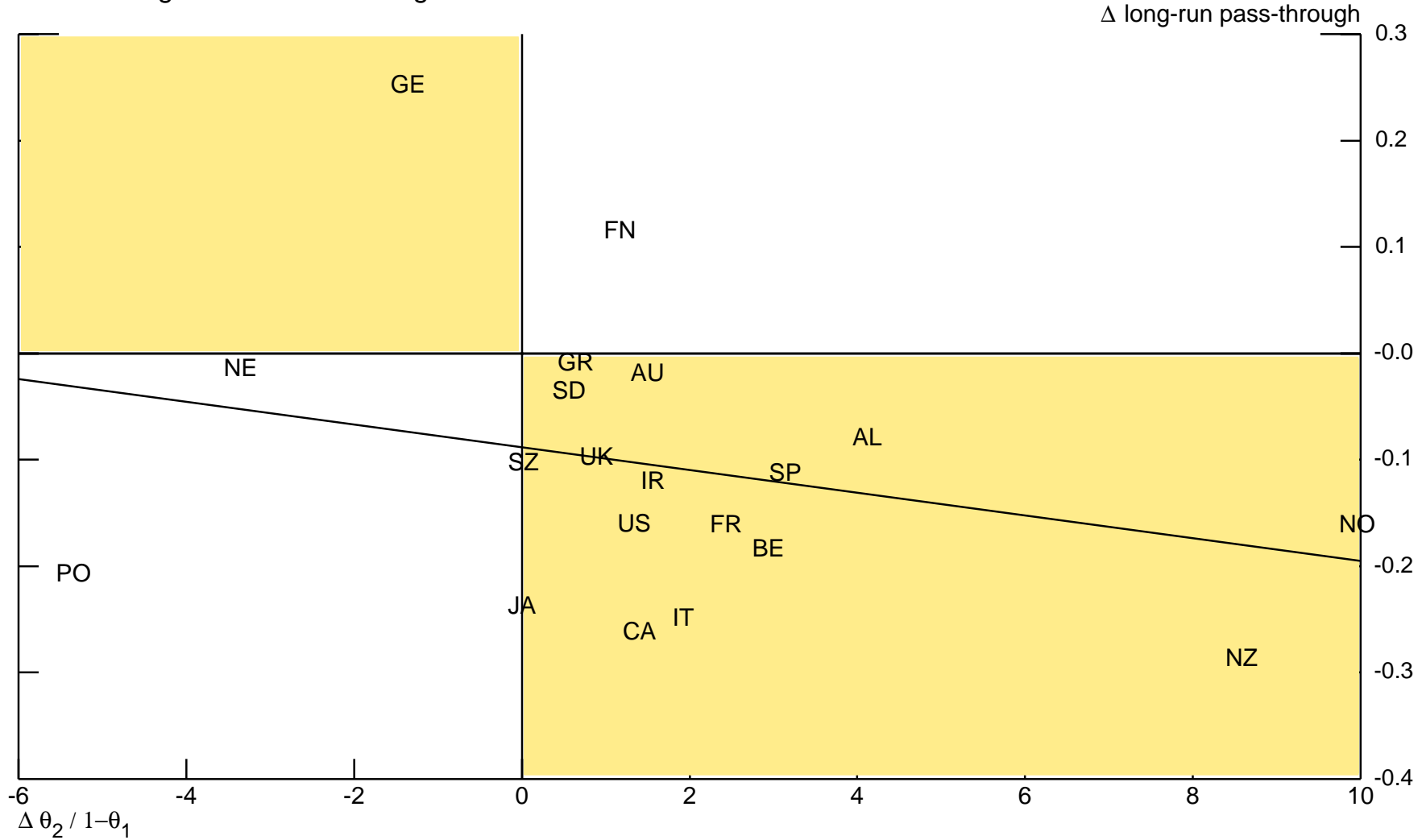

